Revista NEP - Núcleo de Estudos Paranaenses, Curitiba, v.5, n.1, jun. 2019

Dossiê Partidos Políticos e Conexões Familiares

ISSN: $2447-5548$

\title{
PARTIDOS POLÍTICOS OU PARTIDOS DE POLÍTICOS? A RELAÇÃO ENTRE CLÃS FAMILIARES E PARTIDOS POLÍTICOS NO PARANÁ
}

\author{
Eduardo Soncini Miranda ${ }^{1}$ \\ Luiz Fernando Zelinski²
}

\begin{abstract}
Resumo: Investigamos as votações de quinze candidatos as eleições de 2018 no Paraná. Os casos foram escolhidos pois buscamos pesquisar o impacto desses candidatos serem também presidentes de seus partidos políticos em nível estadual. Para tal, investigamos o histórico político familiar e a distribuição dos votos nas últimas eleições 2018. Como hipótese, artigo admite que a estrutura familiar dos presidentes conta para as estratégias políticas dentro dos partidos no Paraná. Os resultados deste estudo apontam para o fato de que possuir um histórico político e familiar é significativo para a conquista da presidência de partidos políticos, independentemente do âmbito em que se dispute a eleição (diferentes cargos: âmbito estadual/federal).
\end{abstract}

Palavas-chave: Presidentes de Partidos; Eleições; Família; Parentesco.

\section{POLITICAL PARTIES OR PARTIES OF POLITICIANS? THE RELATIONSHIP BETWEEN FAMILY CLANS AND POLITICAL PARTIES IN PARANÁ}

\begin{abstract}
We investigated the votes of fifteen candidates in the last 2018 election. The cases were chosen because we sought to investigate the impact that these candidates are also presidents of their political parties at the state level. To do this, we investigate the political family history and the distribution of votes. As hypothesis, article admits that being a party president at the state level influences the elaboration of electoral strategies. The results of this study point to the fact that having a political and family history is significant for winning the presidency of political parties, regardless of the scope of the election.
\end{abstract}

Key words: Presidents of Parties; Elections; Family.

\section{Introdução}

Investigamos as origens familiares históricas e as votações de quinze candidatos a eleição de 2018 no Paraná. Os casos foram escolhidos devido ao fato de que esses políticos além de candidatos são respectivamente presidentes de seus partidos políticos em nível estadual. Neste sentido, buscamos

\footnotetext{
${ }^{1}$ Eduardo Soncini Miranda, é doutor em Ciência Política pela Universidade Federal do Paraná.

Endereço Eletrônico: eduardomiranda@ufpr.br

${ }^{2}$ Luiz Fernando Zelinski, é mestrando em Ciência Política pela Universidade Federal do Paraná. Endereço Eletrônico: fernandozelinski@ufpr.br.
} 
Revista NEP - Núcleo de Estudos Paranaenses, Curitiba, v.5, n.1, jun. 2019

estabelecer conexões e padrões entre as votações de candidatos presidentes de partidos em relação a questões de genealogia/parentesco político.

Os quinze casos selecionados foram: Fernando Francischini (PSL), Maria Victoria (PP), Ademar Traiano (PSDB), Marcio Pacheco (PPL) e Dr. Batista (PMN) eleitos deputados estaduais. Dos candidatos a deputados federais, analisamos os casos de Rubens Bueno (PPS), Pedro Lupion (DEM), Giacobo (PR), Toninho Wandscheer (PROS) que foram eleitos, e o candidato a deputado federal Takayama (PSC), não eleito. Por último pesquisamos o candidato ao senado Alex Canziani (PTB), não eleito e os candidatos ao governo do Paraná, Florisvaldo Fier (Dr. Rosinha - PT), Joao Arruda (MDB), Geonisio Cesar Marinho (PRTB) e Carlos Massa Júnior (Ratinho Jr - PSD), esse último, eleito governador

A estrutura do artigo se divide, no primeiro momento, em uma introdução e a elucidação do contexto familiar dos candidatos na política paranaense. Em segundo, se discute os materiais e métodos para a análise da distribuição de votos dos mesmos.

Os resultados deste estudo apontam para o fato de que possuir um histórico político familiar é significativo para a conquista da presidência de partidos políticos no Paraná, impactando assim as estratégias de campanha dos partidos políticos paranaenses em geral.

\section{Presidência de Partidos: justificando os casos selecionados}

Atualmente o Brasil conta com mais de trinta partidos políticos ${ }^{3}$. Para uma primeira aproximação, buscamos selecionar os partidos políticos que conquistaram cadeiras na Assembleia Legislativa do Paraná (ALEP). Restaram apenas vinte agremiações (PSL, PSB, PT, MDB, PSD, PSC, PSDB, PR, PP, PTB, PRB, PPS, PV, PROS, PRTB, PPL, DEM, PDT, PMN, PODE). A lista de

\footnotetext{
${ }^{3}$ Fonte: TSE. Lista de Partidos: Partido Social Democrático (PSD), Partido Verde (PV), Movimento Democrático Brasileiro (MDB), Avante - AVANTE, Partido Pátria Livre (PPL), Partido Trabalhista Brasileiro (PTB), Progressistas (PP), Partido Democrático Trabalhista (PDT), Partido Socialista dos Trabalhadores Unificado (PSTU), Partido dos Trabalhadores (PT), Partido Comunista Brasileiro (PCB), Democratas (DEM), Partido Comunista do Brasil (PC do B), Partido Renovador Trabalhista Brasileiro (PRTB), Partido Humanista da Solidariedade (PHS), Partido Socialista Brasileiro (PSB), Partido da Social Democracia Brasileira (PSDB), Democracia Cristã (DC), Partido Trabalhista Cristão (PTC), Partido da Causa Operária (PCO), Partido Social Liberal (PSL), Partido Social Cristão (PSC), Partido da Mobilização Nacional (PMN), Partido Republicano Brasileiro (PRB), Partido Socialismo e Liberdade (PSOL), Partido Republicano Progressista (PRP), Partido da República (PR), Partido Popular Socialista (PPS), Partido Patriota (PEN), Partido Republicano da Ordem Social (PROS), Solidariedade - SD, Partido Novo, Rede Sustentabilidade, Partido da Mulher Brasileira (PMB), Podemos (Pode).
} 
Revista NEP - Núcleo de Estudos Paranaenses, Curitiba, v.5, n.1, jun. 2019

presidentes estaduais por partidos políticos com representação na ALEP em 2018 se apresenta da seguinte maneira:

TABELA 1 - AGREMIAÇÕES NA ALEP E SEUS RESPECTIVOS PRESIDENTES ESTADUAL E NACIONAL/2018

\begin{tabular}{lll}
\hline PARTIDO & PRESIDENTE ESTADUAL & PRESIDENTE NACIONAL \\
\hline PSL & Fernando Destito Francischini & Luciano Caldas Bivar \\
PSB & Severino Nunes de Araújo & Carlos Roberto Siqueira de Barros \\
PT & Florisvaldo Fier & Gleisi Helena Hoffmann \\
MDB & João Arruda & Romero Jucá Filho \\
PSD & Carlos Roberto Massa Junior & Gilberto Kassab \\
PSC & Hidekazu Takayama & Everaldo Dias Pereira \\
PSDB & Ademar Traiano & Geraldo José Rodrigues Alckmin Filho \\
PP & Maria Victoria Barros Borghetti & Ciro Nogueira Lima Filho \\
PTB & Alex Canziani Silveira & Roberto Jefferson Monteiro Francisco \\
PPS & Rubens Bueno & Roberto João Pereira Freire \\
PPL & Márcio Pacheco & Sérgio Rubens de Araújo Torres \\
DEM & Pedro Deboni Lupion Mello & Antônio Carlos Magalhães Neto \\
PMN & Manoel Batista da Silva Junior & Antônio Carlos Bosco Massarollo \\
PDT & Osmar Fernandes Dias & Carlos Lupi \\
PR & Fernando Lucio Giacobo & Antonio Carlos Rodrigues \\
PRB & Valdemar Bernardo Jorge & Marcos Pereira \\
PV & Francisco Caetano Martin & José Luiz Penna \\
PROS & Toninho Wandscheer & Eurípedes de Macedo Júnior \\
PRTB & Geonisio Cesar Marinho & Levy Fidelix \\
PODE & Augustinho Zucchi & Renata Abreu \\
\hline
\end{tabular}

FONTE: Os autores, a partir de dados do TSE.

Se constata que dos vinte presidentes de partidos com representação na ALEP, houve uma variedade de candidatos a diversos pleitos eleitorais e outros nomes que não disputaram as eleições em 2018. Muitos presidentes de partidos políticos no Paraná concorreram por vagas na Assembleia Legislativa do Paraná, na Câmara dos Deputados, no Senado Federal (Alex Canziani/PTB) e até mesmo para o Governo do Estado do Paraná (casos de Geonisio Cesar Marinho do PRTB, João Arruda do MDB, Doutor Rosinha do PT, e de Ratinho JR. do PSD, (eleito governador). Os presidentes estaduais Osmar Dias (PDT), Severino Araújo (PSB), Francisco Caetano Martin (PV), Augustinho Zucchi (PODE) e Valdemar Bernardo Jorge (PRB) não disputaram as eleições em 2018.

\section{Presidência de Partidos: família importa? Quem são os líderes paranaenses?}

A teoria do nepotismo pesquisa elementos dos poderes políticos explicados pelas relações de parentesco. As famílias, os capitais sociais, os capitais políticos familiares importam e explicam muito 
Revista NEP - Núcleo de Estudos Paranaenses, Curitiba, v.5, n.1, jun. 2019

Dossiê Partidos Políticos e Conexões Familiares

ISSN: $2447-5548$

sobre as origens, ações, mentalidades e comportamentos das elites da classe dominante. Em uma frase: "Família ainda importa" (OLIVEIRA, p. 08, 2012), sobretudo para a explicação da ação política, compreensão do padrão de recrutamento no parlamento e as formas de atuação da classe dominante em nosso país. "Redes familiares controlam partidos políticos, controlam o centro do poder executivo e formam redes atravessando o poder legislativo com parlamentares hereditários, sempre se renovando pelas gerações". (OLIVEIRA, p.13, 2012).

\section{Os casos dos candidatos a Deputado Estadual na eleição de 2018 - Paraná}

PSL - Presidência- Delegado Francischini

O candidato Delegado Francischini, presidente do PSL paranaense, obteve 427.749 votos e tornou-se o deputado estadual mais votado da história do Paraná - ou seja, ele obteve 7,5\% do total de votos gerais. O PSL conquistou o maior número de cadeiras na ALEP nas eleições de 2018, com oito das 54 vagas. Recentemente, a Procuradoria Regional Eleitoral (PRE) do Ministério Público Federal (MPF) pediu a cassação do mandato e a inelegibilidade por oito anos de Fernando Francischini (PSL) por divulgação de "notícias falsas acerca de lisura do pleito eleitoral" e "promoção pessoal e partidária no dia da eleição"4.

O filho de Fernando Francischini, Felipe Francischini é advogado e também é filiado ao PSL, já era deputado estadual desde 2014 e disputou uma cadeira federal, obtendo a segunda maior votação para deputado federal pelo Paraná nas eleições de 2018, com 241.537 votos.

No começo de 2018, pai e filho, conseguiram conquistar outro feito: são comandantes, respectivamente e concomitantemente, das duas comissões permanentes mais importantes de suas respectivas casas legislativas: a Comissão de Constituição e Justiça (CCJ) na ALEP e a Comissão de Constituição e Justiça e de Cidadania (CCJC) federal na Câmara de Deputados.

A mulher de Fernando Francichini, Flávia Carolina Resende Jaber Francischini já tinha sido nomeada Diretora do Detran do Paraná. Já havia passado pela Sanepar e pela secretária de segurança do Paraná (SESP). Os "Francischinis" também garantiram a eleição de Flávia Francischini, para o posto de secretária-geral da executiva nacional do PSL. Além da função partidária, Flávia pertence aos

\footnotetext{
4 Disponível em: < https://g1.globo.com/pr/parana/noticia/2018/11/30/mpf-pede-a-cassacao-de-francischini-psl-pordivulgar-de-noticias-falsas-no-dia-das-eleicoes.ghtml >. Acesso em: 5 fev. 2019
} 
Revista NEP - Núcleo de Estudos Paranaenses, Curitiba, v.5, n.1, jun. 2019

quadros da Polícia Federal e recentemente foi nomeada na Companhia de Tecnologia da Informação e Comunicação do Paraná (CELEPAR), com salário de aproximadamente R 21 mil em março de 2019. 5

\section{PP - Presidência - Maria Victoria Barros}

A presidente do PP paranaense, a deputada estadual Maria Victória (PP), foi reeleita para seu segundo mandato na ALEP com 50.414 votos em 2018. Segundo pesquisa recente, Maria Victoria estudou Turismo na Suíça e estagiou por 5 meses no hotel Sofitel, em Suzhou, na China. Atualmente cuida dos negócios da família: a St. James International School, a Borghetti Barros Imóveis e a Construtora Magalhães Barros ${ }^{6}$.

Maria Victoria é filha do ex-ministro da saúde do governo Temer, Ricardo Barros (PP) e de Cida Borghetti (PP) vice-governadora do Paraná - no governo Beto Richa. Cida Borghetti disputou o governo do Estado, ficando em segundo lugar nas eleições de 2018. Maria Victoria já havia sido eleita deputada estadual em 2014, com 45.870 votos.

Os pais de Maria Victoria são: Ricardo Barros e Maria Aparecida Borghetti. Cida Borghetti seu nome político - iniciou sua militância na juventude do PDS, filiando-se ao PFL - que o marido também integrava -, depois passou pelo PP até assumir a presidência estadual do Partido Republicano da Ordem Social - PROS e voltar ao PP. A primeira candidatura de Cida Borghetti foi em 2000, quando disputou a Prefeitura Municipal de Maringá pelo PP, obteve 22.931 votos, ficando em quarto lugar. Dois anos após, em 2002, foi candidata a deputada estadual, dobrando com o marido - então candidato a deputado federal, obteve 53.225 votos, elegendo-se. Em 2006, foi novamente candidata, sendo eleita com 66.492 votos. A última candidatura ocorreu em 2010, quando disputou uma vaga para a Câmara dos Deputados e elegeu-se com 147.910 votos. Em 2014, foi eleita vice-governadora na chapa com Beto Richa e em 2018 disputou o governo do Paraná, sendo derrotada no primeiro turno por Ratinho $\mathrm{Jr}(\mathrm{PSD})$.

A família Barros está presente na política maringaense desde a criação do município. $\mathrm{O}$ avô de Maria Victoria era Silvio Magalhães Barros que foi vereador suplente durante a legislatura de 1960

\footnotetext{
5 Portal da Transparência do Paraná. Disponível em: http://www.transparencia.pr.gov.br/pte/home;jsessionid=xncSplpeArlomm9fYyKuapdhfyAFfkfRjG8MBcbd.ssecs75004 ?windowId=a8b >. Acesso em: 1 mai. 2019

6 Disponível em: < https://www.brasildefato.com.br/2016/09/26/maria-victoria-pp-herdeira-das-velhas-oligarquias/ >. Acesso em: 5 mar. 2019
} 
Revista NEP - Núcleo de Estudos Paranaenses, Curitiba, v.5, n.1, jun. 2019

a 1964, representando a UDN (União Democrática Nacional). Em 1966, foi eleito deputado estadual e em 1970 foi eleito deputado federal pelo MDB (Movimento Democrático Brasileiro). Foi ainda prefeito de Maringá em 1972. Casado com Bárbara Cecily Barros tiveram dois filhos que se tornariam os futuros políticos paranaenses: Ricardo José Magalhães Barros e Silvio Magalhães Barros II. Ricardo José Magalhães Barros nasceu em 1959. Sua carreira política iniciou-se em 1988, quando foi candidato e eleito prefeito de Maringá com 38.902 votos. Ricardo Barros também foi candidato a deputado federal, em 1994, ainda pelo Partido da Frente Liberal (PFL), obtendo 54.049 votos. Já em 1998, foi reeleito deputado federal pelo Partido Progressista Brasileiro (PPB), atual Partido Progressista, ao qual se mantém filiado até hoje. Com 68.919 votos, ampliou o eleitorado e foi consolidando o posto de deputado federal de Maringá e região. Ricardo reelegeu-se para o terceiro mandato em 2002, com 118.036 votos. Em 2006, com 130.085 votos, foi eleito para o quarto mandato consecutivo. Em 2010, Barros disputou e perdeu a cadeira ao Senado pelo PP. Após a derrota, Barros foi indicado para assumir a Secretaria Estadual da Indústria, do Comércio e de Assuntos do Mercosul no governo Richa. Com o processo de impeachment de Dilma Rousseff (PT), Michel Temer (MDB) indicou Ricardo Barros para ser o Ministro da Saúde.

O tio de Maria Victoria é Silvio Magalhães Barros II nascido em 1956. Sílvio disputou a prefeitura de Maringá pela primeira vez em 1996, obtendo 31.081 votos pelo PFL. Foi eleito pela primeira vez em 2004 pelo PP, obtendo 43.333 votos no primeiro turno e 92.052 no segundo turno para a prefeitura maringaense. Reeleito em 2008, obteve 104.820 votos, representando 57\% do eleitorado.

Atualmente, a presidente do PP paranaense, Maria Victoria (PP) é deputada estadual, empresária e já havia tentado ser prefeita da capital do Paraná. Ela disputou as eleições municipais em 2016, quando tinha apenas 27 anos, ficando em $4^{\circ}$ lugar, com 52,576 votos, ou seja, 5,6\% do total dos eleitores de Curitiba. Victoria declarou bens no valor de R \$ 897.880,05 mil nas eleições de 2016. Sua evolução patrimonial foi maior que 5.000\% em apenas dois anos, de acordo com a declaração feita à Justiça Eleitoral. Em 2014, ela declarou possuir um patrimônio de R\$17.100,00.

PSDB - Presidência - Traiano

Ademar Traiano é advogado e presidente do PSDB no Paraná. É também o presidente do legislativo estadual paranaense e está em seu oitavo mandato. Traiano se elegeu vereador e foi 
Revista NEP - Núcleo de Estudos Paranaenses, Curitiba, v.5, n.1, jun. 2019

presidente da Câmara de Santo Antônio do Sudoeste em 1982. Foi também prefeito da cidade. Eleito deputado estadual pela primeira vez em 1990, foi líder do governo Beto Richa na Assembleia Legislativa e, em 2015, foi eleito presidente. Recentemente o Ministério Público do Paraná (MP/PR) instaurou inquéritos contra o deputado Ademar Traiano (PSDB) no âmbito da Operação Quadro Negro, que investiga desvios de recursos de escolas do Estado. Segundo o MP/PR, o esquema desviou mais de R\$ 20 milhões da reforma e construção de escolas estaduais ${ }^{7}$.

PPL - Presidência - Marcio Pacheco

O policial federal Marcio Pacheco (PPL) disputou em 2012 o pleito por uma cadeira na Câmara de Vereadores de Cascavel, sendo eleito com 1.412 votos e, em seguida, empossado como Presidente do Legislativo para o biênio 2013/2014. Em 2014, Pacheco obteve 24.855 votos sendo eleito deputado estadual. Em 2018 foi reeleito deputado estadual, pela coligação "Do Bem e da Verdade Para Mudar o Paraná" (PPL/REDE/DC) com 39.323 votos.

PMN - Presidência - Dr. Batista

Manoel Batista nasceu em 1953 e é o filho caçula de uma família de 15 irmãos, sendo 4 irmãos adotivos. É casado e pai de 2 filhas. Dr. Batista é médico e foi eleito duas vezes vereador do município de Maringá, nas gestões 1993/1996 e 1997/2000, tendo sido o vereador mais votado da história política de Maringá. Se elegeu deputado estadual pelo PMN, pela $1^{\text {a }}$ vez, em 2006, com 26.174 votos e reeleito em 2010, com 41.891 votos. Atualmente é presidente estadual do PMN que recentemente aumentou seus diretórios de 30 para 160 provisórias municipais. O atual presidente do PRTB no Paraná é Geonisio Cesar Marinho, que foi assessor parlamentar do deputado estadual Dr Batista na ALEP.

\section{Os casos dos candidatos a Deputado Federal na eleição de 2018 - Paraná}

$$
\text { PPS - Presidência - Rubens Bueno }
$$

\footnotetext{
7 Disponível em: < https://g1.globo.com/pr/parana/noticia/2018/08/09/mp-abre-investigacao-contra-ademar-traiano-eplauto-miro-na-quadro-negro.ghtml >. Acesso em: 12 fev. 2019
} 
Revista NEP - Núcleo de Estudos Paranaenses, Curitiba, v.5, n.1, jun. 2019

Rubens Bueno é o presidente do PPS e já foi diretor administrativo da Itaipu Binacional e presidente da Fundação de Ação Social. Foi Secretário Estadual de Justiça, Trabalho e Ação Social (1987-90), deputado estadual (1983-86 e 1987-90), prefeito de Campo Mourão (1993-96) e em 2018 foi eleito para o seu quinto mandato como deputado federal (1991-92,1999-02, 2011-14, 2015-18 e 2019-22). Em 2002 e 2006, foi candidato ao governo do Estado, sendo que em 2004 também disputou a prefeitura de Curitiba, recebendo 20,04\% dos votos e ficando na $3^{\text {a }}$ posição. Em 2012, disputou a prefeitura da capital paranaense como candidato a vice-prefeito.

Recentemente o Ministério Público do Paraná (MP/PR) ofereceu à justiça uma ação civil pública por improbidade administrativa contra quatro políticos do PPS e o diretório estadual do partido. Segundo o MP, funcionários comissionados dos gabinetes parlamentares e da liderança da legenda na ALEP teriam prestado serviço ao diretório local do PPS. Na ação, o órgão pede liminarmente o bloqueio de $\mathrm{R}$ \$11,3 milhões dos bens dos envolvidos para ressarcimento aos cofres públicos, além da perda da função pública e da suspensão dos direitos políticos de cada um por um período de cinco a oito anos. Em 2017, a $5^{\text {a }}$ Vara da Fazenda Pública de Curitiba excluiu o nome de Rubens Bueno da denúncia. $^{8}$

Nascido em Sertanópolis (PR) em 1948, Rubens Bueno é filho de José Bueno Sobrinho e Maria Aparecida Brustolin Bueno. Casado com Rosemaria Eitelwein Bueno, tem três filhos, Renata Bueno (ex-vereadora de Curitiba e ex-deputada na Itália.), Ricardo Bueno e Rubens Bueno II. A filha de Rubens Bueno, Renata Bueno foi casada com Juliano Borghetti, irmão de Cida Borghtetti, ex-vice governadora, esposa do ex-ministro Ricardo Barros, portanto tio de Maria Victoria, atual presidente do (PP). Recentemente o filho de Rubens Bueno, Rubens Bueno II, ganhou um cargo comissionado DAS I, com salário de R $\$ 10$ mil, lotado na casa civil do atual governo Ratinho Jr (PSD) 9 .

\section{DEM - Presidência - Pedro Lupion}

Pedro Lupion é presidente do DEM, ex-deputado estadual e atual deputado federal de primeiro mandato. Conseguiu um feito notável para um recém-chegado: foi indicado pelo presidente Bolsonaro como um dos vice-líderes de seu governo no Congresso. Junto com o pai, Aberlado Lupion

\footnotetext{
${ }^{8}$ Disponível em: < https://www.folhadelondrina.com.br/politica/rubens-bueno-e-ex-deputados-do-pps-teriam-nomeadofantasmas-934401.html >. Acesso em: 12 fev. 2019

9 Portal da Transparência do Paraná. Disponível em: http://www.transparencia.pr.gov.br/pte/home;jsessionid=xncSplpeArlomm9fYyKuapdhfyAFfkfRjG8MBcbd.ssecs75004 ?windowId=a8b >. Acesso em: 5 mai. 2019.
} 
Revista NEP - Núcleo de Estudos Paranaenses, Curitiba, v.5, n.1, jun. 2019

(assessor especial da Casa Civil da Presidência da República - amigo pessoal do ministro Onyx Lorenzoni - que é inclusive padrinho de casamento de seu filho Pedro - e do presidente Bolsonaro). Foi um dos principais responsáveis pela queda do ex-presidente do senado Renan Calheiros (MDB) abrindo espaço para o até então desconhecido senador Davi Alcolumbre também do partido Democratas do Amapá.

A família Lupion é associada historicamente ao político Telêmaco Borba ${ }^{10}$. Telêmaco, deputado estadual por nove legislaturas e prefeito de Tibagi por nove outros mandatos é avô materno de Hermínia Rolim de Moura, com quem Moysés Lupion se casaria em 1930, quando era um empresário em ascensão. O pai dela, Pedro Rolim de Moura, foi um grande proprietário de fazendas e prefeito de Piraí do Sul em três ocasiões.

Moysés Lupion nasceu em 1908, em Jaguariaíva, nos Campos Gerais, filho de um padeiro espanhol, João Lupion de Troya, e de Carolina Wille Lupion. Lupion inicia sua vida política quando se aproxima do interventor de Getúlio Vargas no Paraná, Manoel Ribas, durante o Estado Novo. Moysés Lupion filia-se ao PSD em 1946 e em 1947 é eleito governador, vencendo seu principal adversário, Bento Munhoz da Rocha.

No fim dos anos 1980, Abelardo Lupion foi um dos fundadores e o primeiro presidente da União Democrática Ruralista (UDR) do Paraná. Nas eleições de 1990, concorreu a deputado federal pelo Partido da Reconstrução Nacional (PRN), de Fernando Collor. Em 1995, fundou na Câmara dos Deputados a bancada ruralista. Nos últimos anos, no plano estadual, Aberlardo Lupion (DEM) foi presidente da Companhia de Habitação do Paraná (Cohapar) na gestão de Beto Richa e secretário de Infraestrutura e Logística de Cida Borghetti. Paralelamente, o filho Pedro Lupion (DEM) se reelegia deputado estadual e chegava ao posto de líder do governo de Cida Borghetti (PP) na Assembleia Legislativa.

Recentemente, ainda podemos identificar dois nomes ligados aos "Lupions" em cargos de destaque e de livre nomeação no governo do Paraná. São os casos de Rafaela Marchioratto Lupion Mello e João Roberto Marchiorato Lupion Mello, respectivamente lotados na Casa Civil e Paraná Cidade, ambos com salários superiores a R \$ 10 mil.

PSC - Presidência - Takayama

\footnotetext{
${ }^{10}$ Disponível em: < https://www.plural.jor.br/o-cla-mais-poderoso-da-provincia/ >. Acesso em: 5 mar. 2019
} 
Revista NEP - Núcleo de Estudos Paranaenses, Curitiba, v.5, n.1, jun. 2019

Takayama (PSC) é filho de Antonio Izami Takayama e Maria Schizuka Takayama. Eleito vereador em Curitiba de 1989 a 1993 foi presidente da Comissão de Legislação e Justiça da Câmara Municipal; em 1992 foi candidato a vice-prefeito de Curitiba e no ano de 1996 foi eleito deputado estadual. Em 1999 foi reeleito pelo PFL com 37.169 votos. Takayama é pastor e empresário do ramo de livros e comunicações. Segundo site da igreja ${ }^{11}$, Takayama estava preocupado com o surgimento de leis que poderiam prejudicar a liberdade da Igreja, e foi para o Congresso Nacional, a pedido da Convenção Paranaense e da Convenção Geral da Assembleia de Deus. Teve uma atuação determinante em favor dos interesses do povo evangélico, especialmente na construção de um texto favorável às Igrejas no novo Código Civil.

O deputado Takayama é ainda hoje pastor auxiliar da igreja evangélica Assembleia de Deus em Curitiba (PR), atualmente com 80 mil membros e cujo titular é o Pastor José Pimentel de Carvalho, ex-Presidente da Convenção Geral. Takayama é casado com Ingrid Takayama (sócia da Rádio Dimensão Fm Ltda) e tem três filhas, Priscila, Patrícia (que foi servidora comissionada, "Assessor Especial - DAS-4" na Secretaria de Saúde do Paraná) e Poliana (também sócia da Rádio Dimensão Fm Ltda). Takayama filiou-se ao PST, o qual foi presidente regional. Teve passagem polêmica e meteórica também no PSB, onde enfrentou questionamentos ao desobedecer a orientação do partido e votar a favor da privatização da Companhia Paranaense de Energia (COPEL) ${ }^{12}$. Em 2011, o Supremo Tribunal Federal (STF) aceitou uma denúncia contra ele, feita pelo Ministério Público Federal (MPF). O parlamentar foi acusado de desviar os salários de 12 pessoas que trabalharam para ele entre os anos de 1999 e 2003, quando ocupou o cargo de deputado estadual no Paraná ${ }^{13}$.

Em 2008, o Ministério Público Federal (MPF), apresentou denúncia contra Takayama, a AP 647, na qual Takayama é denunciado por 12 práticas de peculato, no esquema que ficou conhecido como "Gafanhoto". Os crimes teriam ocorrido entre 1999 e 2003, quando teriam sido contratados funcionários fantasmas, isto é, que não trabalhavam efetivamente, na Assembleia Legislativa (ALEP). Segundo o MPF, os servidores, registrados como comissionados no gabinete, atuavam na casa do parlamentar ou num estúdio de gravações de canções e programas evangélicos de propriedade do político e atual líder da bancada evangélica na Câmara Federal. Alguns funcionários sequer teriam

\footnotetext{
${ }^{11}$ Disponível em: < http://www.cgiadb.com.br/noticias-evangelicas/pastor-hidekazu-takayama/ >. Acesso em: 12 fev. de 2019

12 Disponível em: < https://www.folhadelondrina.com.br/politica/privatizacao-da-copel-alavanca-crise-partidaria355105.html >. Acesso em: 12 fev. 2019

13 Disponível em: < https://www.gazetadopovo.com.br/vida-publica/confira-a-lista-completa-dos-suspeitos-deenvolvimento-no-esquema-gafanhoto-e-suas-respostas-bjqd46388jr2emon8mnz0hopa/ >. Acesso em: 12 fev. 2019
} 
Revista NEP - Núcleo de Estudos Paranaenses, Curitiba, v.5, n.1, jun. 2019

conhecimento de que estavam nomeados pela Casa ${ }^{14}$. Takayama foi ainda membro da Mesa Diretora da Câmara, sendo $4^{\circ}$ Suplente, no biênio 2013-2014.

PR - Presidência - Giacobo

O deputado federal Fernando Lucio Giacobo nasceu em Pato Branco/PR em 1970. É filho do empreiteiro e comerciante de móveis Irineu Luís Giacobo e de Joeci Tartari Giacobo. Giacobo é presidente do PR paranaense e foi eleito para seu quarto mandato em 2018 , atualmente ocupa a $1^{\circ}$ Secretaria na Câmara dos Deputados. Em 2002, Giacobo foi eleito deputado federal pela primeira vez com mais de 52 mil votos pelo PPS, o deputado quase dobrou a votação, sendo reeleito em 2006, pelo PL (Partido Liberal), com 92.868 votos, em 2010, foi reeleito com 120 mil votos. Neste período também, tornou-se presidente estadual do PR. Em 2014, Giacobo foi eleito para o quarto mandato com 145 mil votos. Em 2010, os deputados federais Giacobo (PR) e Alceni Guerra (DEM) foram absolvidos pelo STF do crime de fraude de licitação em um contrato de concessão de para exploração privada da rodoviária de Pato Branco/PR em 1998.

PROS - Presidência - Toninho Wandscheer

Antônio Wadscheer é engenheiro civil e presidente do PROS. Foi prefeito de Fazenda Rio Grande/PR por dois mandatos consecutivos, 2000 e 2004. De 2007 a 2008 presidiu a Assomec (Associação dos Municípios da Região Metropolitana de Curitiba). De 2009 a 2010 assumiu a direção técnica da Comec (Coordenação da Região Metropolitana de Curitiba). De 2010 a 2014, foi eleito deputado estadual pelo PT com 53.457 votos. Em 2014 foi eleito deputado federal pelo PT, com uma votação de aproximadamente 72 mil votos. Em 2015, se desliga do PT e ingressa PMB. Em 2016, filiase PROS. Em 2018, foi reeleito deputado federal pelo PROS, obtendo 72.475 votos. Toninho é paranaense de Foz do Iguaçu, é filho de Paulo e Maria Wandscheer, e nasceu em 1950. É casado com Ângela Wandscheer, e tem três filhos (Alisson, Marcos e Tiago Wandscheer). Seu filho Alisson Wandscheer já foi vereador e presidente da câmara de Fazenda Rio Grande/PR, é presidente estadual do Partido da Mulher Brasileira (PMB) e primeiro suplente na ALEP. Seu outro filho, Tiago Henrique

\footnotetext{
${ }^{14}$ Disponível em: < https://www.folhadelondrina.com.br/politica/depois-de-dez-anos-processo-contra-takayama-voltapara-o-parana-1006069.html >. Acesso em: 12 fev. 2019
} 
Revista NEP - Núcleo de Estudos Paranaenses, Curitiba, v.5, n.1, jun. 2019

Dossiê Partidos Políticos e Conexões Familiares

ISSN: 2447-5548

Wandscheer, também já foi presidente de partido, em 2015 assumiu a presidência do diretório estadual do PROS.

Alisson Wandscheer está atualmente lotado na $1^{\mathrm{a}}$ secretária da ALEP, com salário superior a $\mathrm{R} \$ 14 \mathrm{mil}^{15}$.

\section{O caso do candidato a Senador na eleição de 2018 - Paraná}

PTB - Presidência - Alex Canziani

Alex Canziani é filho de Ody Silveira e Vera Maria Canziani Silveira. Começou a trabalhar em 1984 como oficial registrador de imóveis no cartório do $2^{\circ}$ Ofício de Registro de Imóveis em Londrina. No ano seguinte ingressou no curso de direito da Universidade Estadual de Londrina (UEL). Começou sua militância política como presidente do centro acadêmico do curso de direito de 1987 a 1988 . Formou-se em direito pela UEL em 1990 e foi vereador em Londrina por duas legislaturas, de 1989 a 1992 e de 1993 a 1996, tendo sido presidente da Câmara de Vereadores da cidade em 1993. Em 1992, tornou-se também presidente do diretório municipal do PTB e, de 1993 a 1999, presidiu a Associação dos Vereadores do Médio Paranapanema (Avempar). Em 1996 assumiu o cargo de vice-prefeito de Londrina e, de 1997 a 1998, foi presidente da Companhia de Desenvolvimento de Londrina (Codel). Foi eleito vice-prefeito da cidade, em 1996, na chapa de Antônio Casemiro Belinati. Em 1999 ocupou o cargo de Secretário estadual de Emprego e Relações do Trabalho do Paraná, no governo de Jaime Lerner. Em 1998, foi eleito deputado federal, com 74.876 votos, pelo PTB. Em 2002 reelegeu-se, com 76.195 votos. Tentou a prefeitura de Londrina em 2004, mas foi derrotado ainda no primeiro turno, com apenas 5.081 votos (1,90\% dos votos válidos). Na sequência foi reeleito deputado federal, em 2006, com 111.472 votos. Novamente eleito para a Câmara dos Deputados, com 149.693 votos, foi o quarto mais votado do estado em 2010. Foi reeleito deputado federal em $2014^{16}$.

Alex Canziani responde no STF a um inquérito que tramita em segredo de Justiça desde 2012. Ele é acusado de estelionato, crime de quadrilha ou bando e falsidade ideológica. Com relatoria do

\footnotetext{
${ }^{15}$ Portal da Transparência ALEP. Disponível em: < http://transparencia.alep.pr.gov.br/ >. Acesso em: 1 mai. 2019

16 Disponível em: < http://www.fgv.br/Cpdoc/Acervo/dicionarios/verbete-biografico/canziani-alex >. Acesso em: fev. 2019
} 
ministro Luiz Fux, o inquérito 3544 foi enviado à Procuradoria-Geral da República em novembro do ano passado ${ }^{17}$.

No mês de junho do ano de 2009, o CNJ editou duas resoluções que alterariam a situação dos titulares interinos dos cartórios, através da Resolução $n^{\circ} 80$ que viria a regulamentar as regras para o ingresso nos cartórios, enquanto a Resolução $\mathrm{n}^{\circ} 81$ declararia vagos todos os cargos ocupados em desacordo com as normas constitucionais de 1988 (sem concurso). Tais medidas fariam com que fosse organizado um lobby de tabeliães interinos, objetivando a aprovação da PEC dos Cartórios no Congresso. Um dos defensores de tal medida foi o Deputado Federal do PTB/PR - Partido Trabalhista Brasileiro PTB/PR - (gestões 1999-2003, 2003-2007, 2007-2011). Canziani possui cartório na cidade de Londrina-PR, denominado $2^{\circ}$ Serviço de Registro de Imóveis, onde tomou posse como Titular no ano de 1984. No período de 01/01/2005 até 31/12/2005, tinha declarado renda cartorial no valor de R\$ 964.763,2253. Sua mãe, Vera Maria Canziani Silveira, consta como Substituto neste mesmo estabelecimento. (MACHADO, 2016)

A filha de Alex Canziane, Luísa Canziani (PTB) é a mais nova entre os 513 deputados federais eleitos em 2018 para a Câmara dos Deputados. Luísa nasceu em 11 de abril de 1996 e atualmente é estudante de Direito. Luísa ficou em décimo oitavo lugar entre os 30 eleitos da bancada do Paraná, contabilizando mais de 90 mil votos na sua primeira eleição disputada. O pai, Alex Canziani fez 1.304.719 (12,87\% dos válidos) para o Senado, mas acabou derrotado.

\section{Os casos dos candidatos a Governador do Estado na eleição de 2018 - Paraná}

$$
\text { PT - Presidência - Dr Rosinha }
$$

Filho de Sebastião Basílio Fier e Uracy Sanches Fier. Sebastiao foi agricultor familiar na região de Rolândia. Florisvaldo começou a trabalhar ainda adolescente como agricultor familiar ao mesmo tempo em que se dedicava aos estudos. Em 1969 mudou-se para Curitiba, onde concluiu o ensino médio e, a partir de 1971, frequentou o curso de medicina na Pontifícia Universidade Católica (PUC) do Paraná formando-se em 1976. Nessa época, Dr. Rosinha começou a atuar nos movimentos sociais, foi um dos fundadores e diretor do Sindicato dos Servidores Públicos Municipais (Sismuc) e diretor

\footnotetext{
${ }^{17}$ Disponível em: < http://portal.stf.jus.br/processos/listarPartes.asp?termo=alex\%20canziani >. Acesso em: fev. 2019
} 
Revista NEP - Núcleo de Estudos Paranaenses, Curitiba, v.5, n.1, jun. 2019

do Centro Brasileiro de Estudos da Saúde. Também participou da fundação do Partido dos Trabalhadores (PT) e da Central Única dos Trabalhadores (CUT), no início dos anos 80.

Doutor Rosinha foi eleito vereador de Curitiba, em 1988, sendo o candidato mais votado do partido. Em 1990, venceu a eleição para deputado estadual e, em 1998, tornou-se deputado federal. Em Brasília, iniciou-se uma nova etapa de luta. Nas eleições de 2002, obteve uma votação histórica: mais de 124 mil votos. Nos últimos anos, foi presidente e secretário-geral da Comissão do Mercosul do Congresso Nacional.

Em 7 de maio de 2007 foi eleito vice-presidente do Parlamento do Mercosul (Parlasul). Exerceu a presidência da entidade de junho de 2008 até fevereiro de 2009. Em agosto de 2018, foi confirmado candidato do Partido dos Trabalhadores ao governo do Estado, em chapa pura. Tendo a militante Anaterra Viana como vice. Ficou em $4^{\circ}$ lugar no pleito, tendo recebido 463.494 votos $(8,66 \%$ dos votos válidos $)^{18}$.

PSD - Presidência - Ratinho Jr.

Carlos Roberto Massa Júnior nasceu em Jandaia do Sul, em 1981. É conhecido como Ratinho Júnior, pois é filho do apresentador de televisão do SBT, Ratinho.

Na televisão, seu pai, o apresentador Ratinho, comandava o programa "190 Urgente" do canal CNT e o programa "Ratinho Livre" na Record. Naqueles tempos o programa do apresentador era mais policial e Ratinho costumava criticar os políticos e a justiça brasileira, já no SBT, seu programa ficou mais cômico e o destaque era o quadro "exame de DNA", exames de paternidade revelados ao vivo no "Programa do Ratinho".

O apresentador Ratinho já havia sido vereador em Jandaia do Sul e Curitiba (PR) entre as décadas de 1970 e 1980 e também deputado federal pelo Paraná entre 1991 e 1995. Em 1988, graças à TV, Ratinho se elegeu vereador em Curitiba, pelo PMDB. Em 1990, com cerca de 40 mil votos, conquistou uma vaga na Câmara dos Deputados pelo então PRN de Fernando Collor de Mello. Já no PTB, em 1992, votou a favor do impeachment de Collor.

O dono do canal CNT, era José Carlos Martinez. Natural de São Paulo (SP), Martinez elegeuse deputado federal pelo Paraná em fevereiro de 1982, pelo Partido Democrático Social (PDS). Pelo PMDB, conquistou o segundo mandato. Em 1992, após o término da legislatura, junto ao irmão Flávio,

\footnotetext{
${ }^{18}$ Disponível em: < https://www.camara.leg.br/deputados/73459/biografia >. Acesso em: fev. 2019
} 
Revista NEP - Núcleo de Estudos Paranaenses, Curitiba, v.5, n.1, jun. 2019

organizou a rede OM (Organizações Martinez) de rádio e televisão, que deu origem à Central Nacional de Televisão (CNT). Retornou à política em 1998, filiado ao PTB, elegendo-se novamente deputado federal. Um ano depois, Martinez assumiu a presidência nacional do partido. Reeleito em 2002, com 62.706 votos, faleceu em 2003, vítima de um acidente aéreo quando se deslocava em um monomotor de Curitiba ao Aeroporto de Navegantes (SC).

Martinez foi tesoureiro da candidatura de Fernando Collor de Mello, quando conseguiu notoriedade e pôde concorrer ao governo do Paraná em 1990, perdendo para Roberto Requião. Em 1992 foi acusado de receber 4,5 milhões de dólares de Paulo César Farias. Os dados fundamentais sobre a conexão PC-Martinez no negócio de TV podem ser conhecidos em processos judiciais arquivados no Distrito Federal e em Alagoas ou, em síntese, com a mera leitura do relatório da CPI do $\mathrm{PC}^{19}$.

Carlos Massa, o "Ratinho pai" é casado com Solange Martinez Massa, com quem teve três filhos: Carlos Massa Júnior e os gêmeos Gabriel e Rafael Massa. Além da carreira na televisão, Ratinho é dono de um grupo de empresas, que lhe conferiram uma das maiores fortunas da TV brasileira. Em agosto de 2011, declarou sobre o filho: "Quem paga a campanha política do meu filho sou eu, ninguém banca nada. Ele não tem patrocinador, tem 'paitrocinador"', conta Ratinho ${ }^{20}$.

O filho, Carlos Massa Júnior, atual governador do Paraná estudou entre 1996 e 1998 no Colégio Ideal, depois formou-se em Marketing e Propaganda na Faculdade Internacional de Curitiba, em 2004 e concluiu a pós-graduação em Direito do Estado pela Pontifícia Universidade Católica de Brasília em 2011.

O governador do Paraná começou sua vida política no Partido Socialista Brasileiro (PSB), do qual foi vice-presidente do diretório estadual em Curitiba de 2001 a 2004. Candidatou-se e foi eleito deputado estadual do Paraná pelo PSB em 2002. Em 2006, candidatou-se a deputado federal pelo Partido Popular Socialista (PPS) e foi eleito com 205 mil votos. Em 2007, filiou-se ao Partido Social Cristão (PSC) pelo qual candidatou-se a reeleição de deputado federal do Paraná, vencendo desta vez com cerca de 360 mil votos. Licenciou-se do mandato em 2012, para concorrer à prefeitura de Curitiba ainda pelo PSC, com a coligação "Curitiba Criativa" (PSC, PCdoB, PR e PTdoB), tendo sido derrotado por Gustavo Fruet no segundo turno. Em 2013, tornou-se secretário de Estado do Desenvolvimento

\footnotetext{
${ }^{19}$ Disponível em: < https://www2.senado.leg.br/bdsf/bitstream/handle/id/88802/CPMIPC.pdf?sequence=4 >. Acesso em: 12 fev. 2019

${ }^{20}$ Disponível em: < https://televisao.uol.com.br/noticias/redacao/2014/03/11/sbt-e-ratinho-sao-condenados-a-pagar-r-41mil-por-danos-morais-a-mulher.htm >. Acesso em: 12 fev. 2019
} 
Revista NEP - Núcleo de Estudos Paranaenses, Curitiba, v.5, n.1, jun. 2019

Urbano do Paraná na gestão Beto Richa (PSDB) cargo que ocupou até 6 de abril de 2014, quando renunciou para concorrer a uma vaga na ALEP, sendo eleito com mais de 300 mil votos. Foi o candidato a deputado estadual mais votado do Brasil proporcionalmente. Retornou ao cargo de secretário no início do segundo mandato de Beto Richa. Em 2018, Ratinho Júnior foi candidato ao governo do Paraná pela coligação "Paraná Inovador", contando com o apoio do PSC, PV, PR, PHS, Avante, PRB e PPS. Atualmente está filiado ao PSD. O candidato a vice na chapa foi o empresário Darci Piana (PSD).

Em seu primeiro discurso como governador eleito, Ratinho criticou as oligarquias familiares, disse que trabalhou por 16 anos para chegar ao Governo do Estado. "Tenho orgulho de ser o primeiro governador eleito nos últimos 40 anos sem fazer parte de nenhuma oligarquia", disse Ratinho Junior, para depois ressaltar sua própria história familiar/política "Tenho orgulho de ter uma história familiar de superação. Se a política me deu os instrumentos para consolidar meu projeto, foi minha família que me deu a base que me sustentou, os meus valores de justiça e de bom senso".

Ratinho Júnior assumiu governo do Paraná em 2019 com um discurso sobre inovação na gestão. Afinado com o discurso do candidato à presidência Jair Bolsonaro (PSL), o governador do Paraná foi eleito com um discurso antipolítico, dizendo na campanha que era "filho do trabalho" e que acabaria "com as práticas da velha política"21.

Já eleito e para associar ações de governo com promessas de campanha, o governador Ratinho Jr anunciou a demissão de todos os comissionados do governo do Paraná como um ato moralizante da gestão. Porém, ao analisarmos com mais cautela as novas nomeações que começaram a ser feitas, por exemplo na agência reguladora de concessões (AGEPAR), onde no passado estava nomeado o filho do deputado Ricardo Arruda (PSD), agora foi nomeada a sobrinha do mesmo parlamentar. Outra nomeação chamou a atenção em 2019, Rubens Bueno II, filho do deputado federal Rubens Bueno, foi nomeado assessor da Casa Civil. Também ex-parlamentares, alguns deles derrotados nas eleições de outubro de 2018, conseguiram nomeações via/no Palácio Iguaçu. São os casos de Rasca Rodrigues, novo diretor-geral da Secretaria de Meio Ambiente; Claudio Palozi nomeado superintende do Serviço Social Autônomo Paraná Educação; o ex-deputado Alexandre Guimarães, nomeado para o cargo de Assessor Especial da Vice-Governadoria ${ }^{22}$; e o ex deputado estadual Luiz Accorsi que assumiu o cargo

\footnotetext{
${ }^{21}$ Disponível em: < http://www.aen.pr.gov.br/modules/debaser/visualizar.php?audiovideo=1\&xfid=80134 >. Acesso em: 12 fev. 2019

22 Guimarães já teve R\$ 47 mil bloqueados pela justiça em 2017, por gastar "dinheiro público de forma abusiva e indiscriminada". Alexandre recorreu da decisão no Tribunal de Justiça e foi inocentado, mas não se reelegeu.
} 
Revista NEP - Núcleo de Estudos Paranaenses, Curitiba, v.5, n.1, jun. 2019

de assessor da governadoria. Dirigentes partidários também não ficaram à míngua. Rodrigo Pina de Almeida, presidente estadual do PHS - partido que apoiou Ratinho nas eleições do ano passado - agora é Assessor Especial da Governadoria com salário equivalente ao de secretário de estado, e Valdemar Bernardo Jorge, presidente do PRB paranaense foi nomeado secretário do planejamento do estado do Paraná.

\section{MDB - Presidência - Joao Arruda}

O deputado federal João Arruda foi candidato do MDB para o Governo do Paraná nas eleições 2018. Sobrinho do senador Roberto Requião, teve a professora Eliana Cortez da Silva, também do MDB, como vice, Eliana era presidente da Câmara de Ribeirão Claro, no Norte do Paraná. A chapa contará com apoio do Solidariedade, do PCdoB e do PDT, que fechou com Arruda após a desistência do pré-candidato Osmar Dias.

João Arruda, além de sobrinho do ex Governador/Senador do Paraná, Roberto Requião, é casado com Paola Malucelli, filha de Joel Malucelli, um dos maiores empresários do Sul do Brasil. O grupo J. Malucelli possui um conglomerado de empresas (construção pesada, corretora de seguros, banco, revenda de equipamentos e geração de energia) com mais de quatro mil funcionários e faturamento superior a um bilhão de reais por ano. Joel Malucelli também é proprietário das rádios CBN e Band News em Curitiba (COELHO, 2017).

Além do sobrinho na presidência do MDB, a família Requião está presente também na ALEP. O filho de Requião é deputado estadual. Maurício Thadeu de Mello e Silva, mais conhecido como Requião Filho, nasceu em Curitiba, em 1979. A carreira do pai no Senado o levou para Brasília, onde acabou se formando em Direito. Originária da Bahia, a família Requião destacou-se, no Paraná, no ramo comercial; Euclides Requião foi o primeiro desse nome na região. Já os Mello e Silva, também de origem nordestina, tiveram pequena notoriedade no campo da política local, tendo um maior destaque no campo intelectual desde o século XIX (RESENDE, 2015).

Em 2018, Malucelli teve a prisão decretada na Operação Rádio Patrulha, do Grupo de Atuação Especial de Combate ao Crime Organizado (Gaeco $)^{23}$. No entretanto, não foi localizado em sua casa

${ }^{23}$ Disponível em: < https://www.gazetadopovo.com.br/politica/parana/gaeco-faz-buscas-na-sede-do-grupo-j-malucellidqru3ymhirofyh42qqco9edji/ >. Acesso em: 4 set. 2018 
em Curitiba pois estaria na Itália, considerado foragido, o empresário apresentou-se a polícia em seguida.

A suspeita era de envolvimento em um esquema de superfaturamento de contratos para manutenção de estradas rurais para o pagamento de propina para agentes públicos. Esses contratos faziam parte do programa Patrulha do Campo. Derrotado no processo de licitação do programa Patrulha do Campo, empresário é gravado reclamando da quantidade de "patrulhas" prometidas a ele ${ }^{24}$. Malucelli é amigo pessoal e suplente (licenciado) do senador Álvaro Dias, candidato à presidência pelo Podemos (e irmão do presidente do PDT/PR, ex senador/governador Osmar Dias). Também é sogro de João Arruda, candidato ao governo do Paraná pelo MDB e primo do candidato a vicegovernador de Cida Borghetii, Coronel Malucelli. Atualmente, encontramos lotada na direção da ALEP, Flávia Malucelli Baltazar com salário de cerca de R\$ 14 mil.

\section{PRTB - Presidência - Geonisio Cesar Marinho}

O presidente estadual do PRTB no Paraná, Geonísio Marinho, foi novamente candidato a governador do Estado. Geonísio é economista e natural de Curitiba. Na política desde 1991, foi candidato a vereador da capital paranaense três vezes, e uma vez em Pontal do Paraná/PR, no litoral do estado, mas nunca foi eleito. Marinho foi secretário do antigo diretório estadual do Partido da Mobilização Nacional (PMN). Também foi assessor do gabinete do deputado estadual Dr. Batista, hoje presidente do PMN no Paraná. No pleito de 2014, ele ficou em sétimo lugar, com pouco mais de 7 mil votos, o equivalente a 0,12\% dos votos válidos. Em 2018, Marinho apostou no resgate da "velha educação" e teve o apoio do PRP. O vice na chapa é Eliceu Palmonari, também do PRTB. Nas eleições de 2018 Geonísio teve 18.021 (0,34\% dos válidos).

\section{Pergunta: família importa?}

Em outras palavras, indagamos: será que o presidente do PPS, deputado federal Rubens Bueno, exerce seu cargo de presidente de partido sendo totalmente imparcial em relação ao total de

\footnotetext{
${ }^{24}$ De acordo com o despacho de Fernando Bardelli Fischer, Joel participou de uma reunião no interior do Departamento de Estradas de Rodagem (DER) junto com outros dois empresários, o colaborador Tony Garcia (que denunciou o suposto esquema) e um funcionário do órgão para deliberarem sobre a conformação dos editais do programa Patrulha Rural. De acordo com a denúncia, a proposta de corrupção consistia em superfaturar os contratos de $\mathrm{R} \$ 72$ milhões do programa e repassar $8 \%$ do faturamento bruto como propina a agentes públicos como contrapartida.
} 
candidaturas à vereança, em seu partido, mesmo sabendo que sua filha, Renata Bueno, fora uma das candidatas à vereadora em Curitiba? Quais são as consequências no tocante a representação política partidária quando identificamos que uma das famílias políticas do Paraná, comanda simultaneamente dois diferentes partidos políticos (PROS e PMB), como no caso da família Wandscheer? Ou ainda, será que o fato do pai e da mãe da atual deputada estadual Maria Victoria (PP) serem respectivamente um ministro de Estado e uma vice-governadora a ajudaram a obter êxito na sua campanha eleitoral? Por fim, será que presidir um partido político favorece a arrecadação de dinheiro para as campanhas eleitorais? Analisaremos nuances da importância do histórico familiar nos partidos políticos paranaenses em relação a votação dos presidentes de partidos políticos que disputaram as eleições de 2018.

\section{A distribuição do voto e o índice de presença eleitoral do candidato (IPE-C)}

Nesta seção apresentamos uma análise descritiva pormenorizada sobre como estão distribuídos os votos dos 15 candidatos que compõem o número de casos estudados. Para tal, calculamos e plotamos o Índice de Presença Eleitoral do Candidato (IPE-C) que é a quantia de votos conquistada pelo candidato sob o total de votos de todos os candidatos no mesmo município. Por fim, é importante estar atento a magnitude eleitoral do município a fim de uma melhor interpretação dos dados.

\section{As votações - o caso dos candidatos a Deputado Estadual - Paraná}

O candidato a deputado estadual pelo Partido Social Liberal (PSL), Fernando Destito Francischini, foi eleito em 2018 com um total de 427.749 votos, a maior conquista de votos à candidatura na história do Estado do Paraná. O candidato foi responsável por cerca de $50 \%$ dos votos de sua coligação (PSL, PTC e PATRI) que somou um total de 808.458 votos e conquistando demais acentos na Assembleia Legislativa do Estado do Paraná (ALEP) ${ }^{25}$. O candidato também alcança a marca de ter feito votos em todos os 399 municípios do Estado.

\footnotetext{
${ }^{25}$ PSL - Delegado Francischini 427.521 mil votos; Coronel Lee 58.336 mil votos; Delegado Fernando 36.935, Luiz Fernando Guerra com 32.207 mil; Missionário Ricardo Arruda 27.565 mil, Do Carmo 17.691 mil, Emerson Bacil 17.625 mil, Subtenente Everton 13.039 mil;
} 
Revista NEP - Núcleo de Estudos Paranaenses, Curitiba, v.5, n.1, jun. 2019

No mapa abaixo será apresentado a distribuição dos votos conquistados nos 399 municípios do Estado. Conforme a legenda a concentração de votos, ou o Índice de Presença Eleitoral do Candidato (IPE-C) no município, variam de $0,001 \%$ até $36 \%$ do total de votos do município. É possível notar que o Delegado Francischini possui grande concentração de votos no entorno da capital paranaense e região metropolitana, região mais populosa do Estado e de maior magnitude eleitoral. Da mesma forma, ocorre alta concentração de votos no norte e parte do centro-oeste do Estado.

É possível destacar ao norte os municípios de Sertanópolis IPE-C 36\% e 3.105 votos, Primeiro de Maio IPE-C 25\% e 1.396 votos e Bela Vista do Paraíso IPE-C 23\% e 1.828 votos, ao sul Salgado Filho IPE-C $20 \%$ e 554 votos. Mais 43 municípios estão em um recorte em que o IPE-C variam entre $8 \%$ e $17 \%$. Em Curitiba, o candidato conquistou um total de 139.839 votos, um IPE-C de $15 \%$ do total de votos da capital.

Vale lembrar que Felipe Francischini (PSL), filho do delegado Francischini, foi o deputado federal mais votado em todos os municípios onde o pai (candidato a deputado estadual) teve maior IPE-C: Em Sertanópolis - Felipe Francischini fez 2.751 votos, 30\% dos votos a deputado federal naquele município, em Primeiro de Maio Felipe fez 1153 votos, 20\% dos votos a deputado federal naquele município, Felipe também foi o campeão de votos a deputado federal em Bela Vista do Paraíso com 2.264 votos (26\%) e no município de Salgado Filho onde obteve 569 votos (20\%), reforçando assim a "dobra pai/filho" do PSL paranaense. 
Revista NEP - Núcleo de Estudos Paranaenses, Curitiba, v.5, n.1, jun. 2019

ISSN: 2447-5548

FIGURA 1 - DISTRIBUIÇÃO DE VOTOS - PERCENTUAL DE VOTOS POR MUNICÍPIO DELEGADO FRANCISCHINI (PSL)

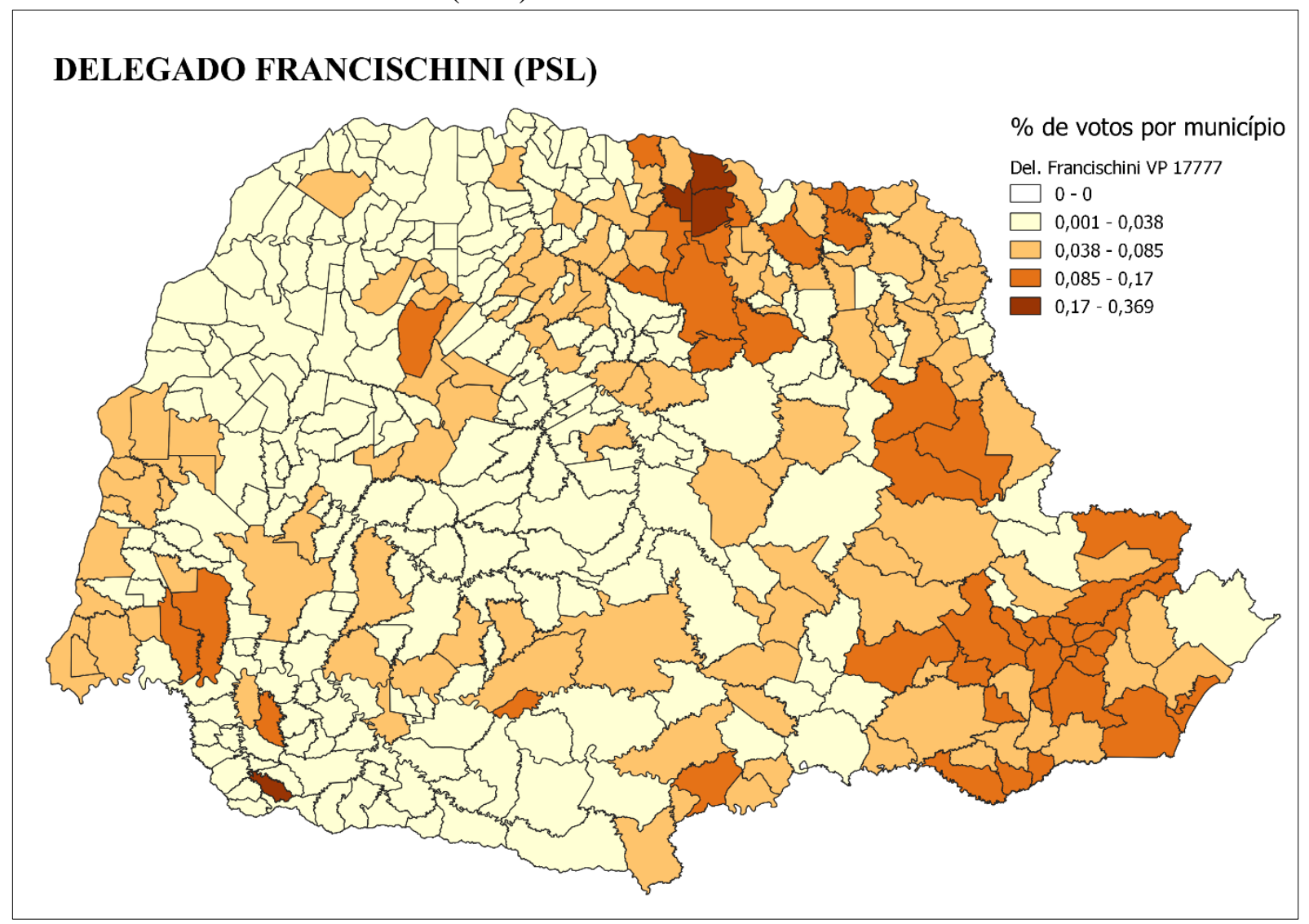

FONTE: Os autores, a partir de dados do TSE.

Maria Victória Borghetti Barros concorreu como deputada estadual pelo Partido Progressista (PP) e foi eleita com um total de 50.414, alcançando $18^{\circ}$ melhor desempenho na conquista de votos, e tendo estes distribuídos em 367 municípios dos 399 que possui o Estado do Paraná. Em dois destes ela alcançou o IPE-C de $52 \%$ e $61 \%$ do total de votos para o cargo naqueles municípios, a saber, respectivamente Antônio Olinto mais ao centro-norte e Quinta do Sol no Sul. Um segundo grupo com 8 municípios se destacam devido ao seu IPE-C, são eles: São Pedro do Paraná IPE-C 33\% e 572 votos, Marilena IPE-C 29\% e 1.031 votos, Nova Aliança do Ivaí IPE-C 20\% e 205 votos, Iretama IPE-C 18\% e 928 votos, Jardim Olinda IPE-C 12\% e 118 votos, Amaporã IPE-C 11\% e 306 votos, Janiópolis IPEC $11 \%$ e 359 votos e Itaúna do Sul IPE-C 11\% e 195 votos. Em Curitiba, a candidata conquistou um total de absoluto de votos de 10.178 IPE-C 1\% e em Maringá, 5.650 IPE-C 3\%.

No município de Antonio Olinto/PR, onde a deputada Maria Victoria foi campeã de votos a deputada estadual, seu pai Ricardo Barros foi o oitavo candidato mais votado a deputado federal no município com 66 votos, 1,5\%. Em Quinta do Sol, a dobra "Pai/filha" também obteve sucesso com 
Revista NEP - Núcleo de Estudos Paranaenses, Curitiba, v.5, n.1, jun. 2019

Maria Victória (PP) campeã de votos para deputada estadual e Ricardo Barros (PP) campeão de votos para deputado federal com 1602 votos, $51 \%$ dos votos a deputado federal da Quinta do Sol/PR. Pai e filha também foram campeões de votos em Nova Aliança do Ivaí, onde Ricardo Barros fez $27 \%$ dos votos, 304 votos para deputado federal naquele município. Em São Pedro do Paraná, Iretama e Jardim Olinda, a dobra Pai e Filha também funcionou, Ricardo Barros ficou em segundo e terceiro lugar nesses municípios respectivamente, com 313 votos 17\% (segundo lugar em São Pedro do Paraná), 562 votos, 10\% (terceiro lugar em Iretama) e 128 votos, 12\% (terceiro lugar em Jardim Olinda).

Em Antonio Olinto/PR há uma família política de muito destaque local: a família Machiavelli. Em 2018 o prefeito eleito foi Fabio Staniszewski Machiavelli (MDB), ele é filho de Itamar de Paula Machiavelli e Regina Geli Staniszewski Machiaveli. Nas mesmas eleições outros dois representantes da família se elegeram vereadores: Tania Machiavelli (PR) e Zeca Machiavelli (MDB). A família Machiavelli aparece no poder local desde de meados do século passado.

Já na legislatura de 1965-1969, a família aparece no poder local municipal com o vereador Adyr Figueira Machiavelli. Na sequência na legislatura 1969/1973, com Ariomar de Paula Machiavelli, passando por Itamar de Paula Machiavelli de 1973 a 1977. Em 1982 já há dois representantes da família no legislativo municipal: Edgar de Paula Machiavelli e Ismar Machiavelli. De 1988 a 1992, volta ao legislativo o ex vereador tamar de Paula Machiavelli, de 1992 a 1996, retorna ao legislativo municipal o ex vereador Ariomar de Paula Machiavelli. Já no século XXI, de 2000 a 2008, há o retorno e a reeleição (2004) de Itamar de Paula Machiavelli, sendo por fim, Fabio F. Machiavelli eleito em 2008 para o legislativo municipal. 
Revista NEP - Núcleo de Estudos Paranaenses, Curitiba, v.5, n.1, jun. 2019

FIGURA 2 - DISTRIBUIÇÃO DE VOTOS - PERCENTUAL DE VOTOS POR MUNICÍPIO MARIA VICTORIA (PP)

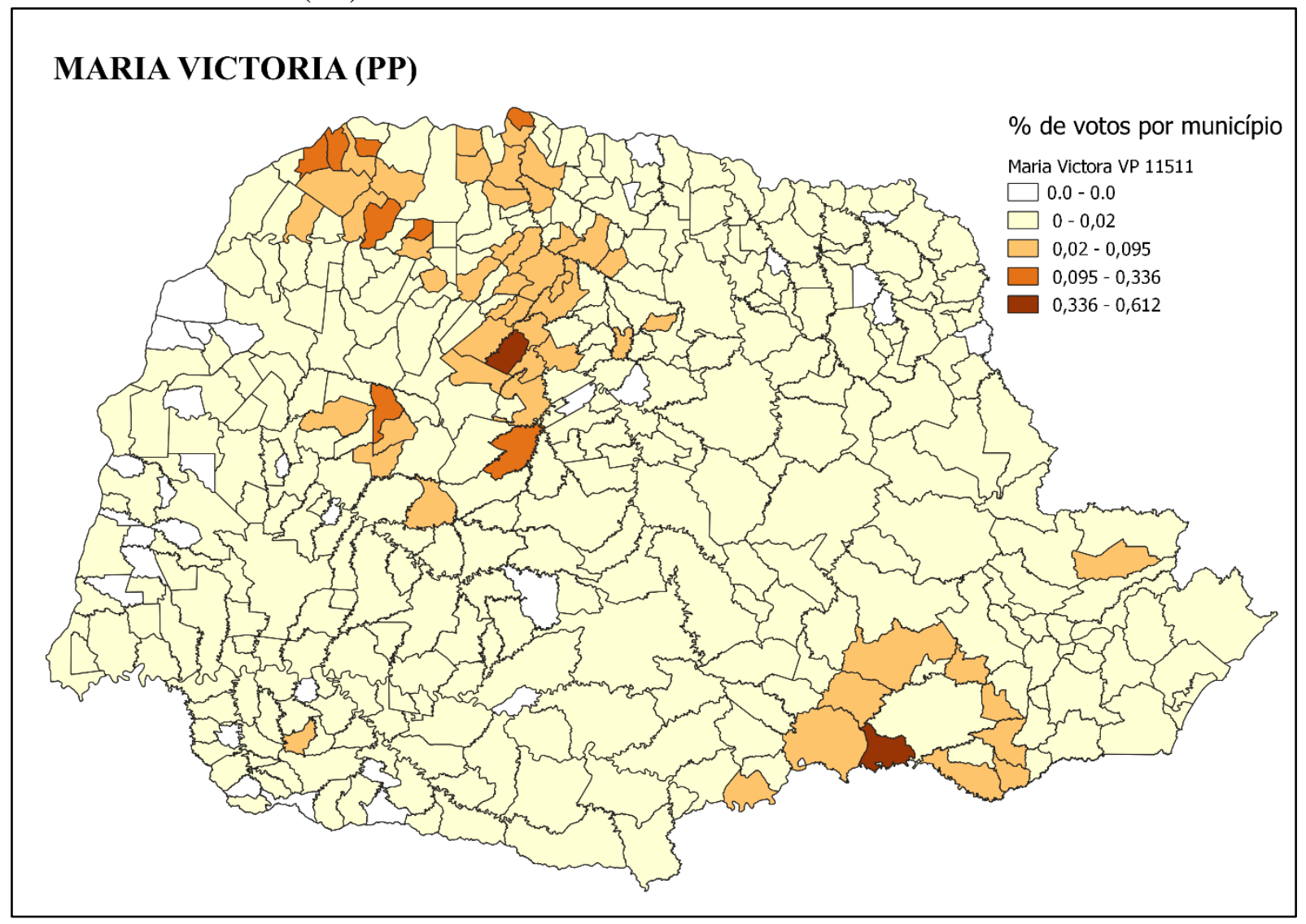

FONTE: Os autores, a partir de dados do TSE.

O candidato a deputado estadual pelo Partido da Social Democracia Brasileira (PSDB), Ademar Luiz Traiano, foi eleito em 2018 com um total de 43.601 votos, alcançando o $26^{\circ}$ melhor desempenho na conquista de votos. Conforme mapa abaixo, é possível observar que o candidato possui um perfil bem mais concentrador de votos, entre a região Sul e Oeste do Estado. Um perfil diferente dos candidatos tratados anteriormente. Oito são os municípios ao qual o candidato apresentou um IPEC que varia entre 19\% e 42\% dos votos, são eles: Bom Sucesso do Sul IPE-C 42\% e 942 votos, Kaloré IPE-C 29\% e 743 votos, Santa Terezinha de Itaipu IPE-C 27\% 3.256 votos, Santo Antônio do Sudoeste IPE-C 26\% e 2.787 votos, Pranchita IPE-C 24\% e 839 votos, Bela Vista de Caroba IPE-C 23\% e 511 votos, Goioxim IPE-C 23\% e 852 votos e Lobato IPE-C 22\% e 570 votos. Outros 19 municípios se encontram em uma faixa IPE-C do candidato que varia de $8 \%$ a 19\%. Em votos absolutos, Ademar Traiano tem sua maior conquista no município de Santa Terezinha de Itaipu. Por fim, conquistou pelo menos 1 voto em 236 cidades do Estado. 
Revista NEP - Núcleo de Estudos Paranaenses, Curitiba, v.5, n.1, jun. 2019

FIGURA 3 - DISTRIBUIÇÃO DE VOTOS - PERCENTUAL DE VOTOS POR MUNICÍPIO ADEMAR TRAIANO (PSDB)

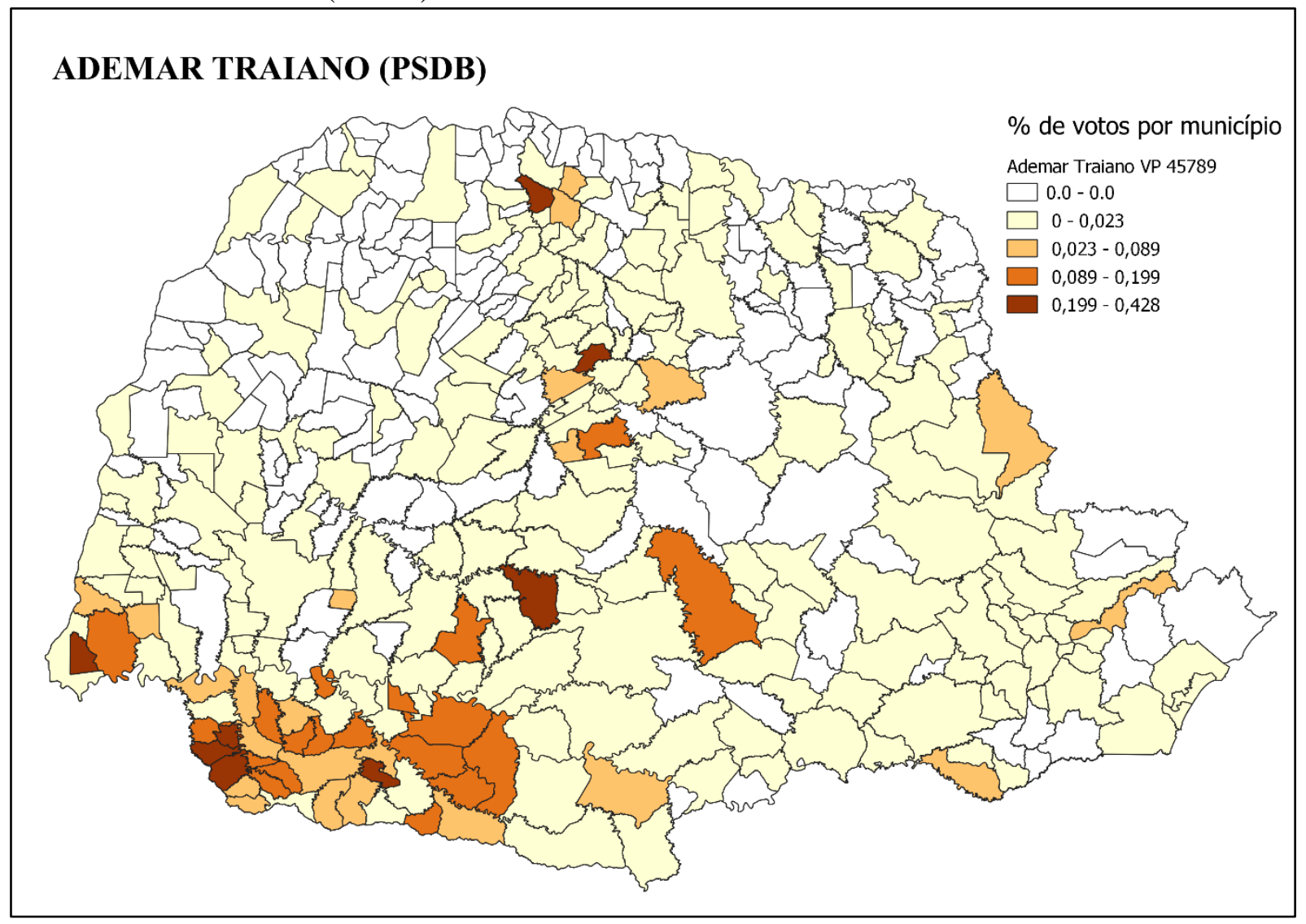

FONTE: Os autores, a partir de dados do TSE.

Marcio Jose Pacheco Ramos, foi candidato a deputado estadual pelo Partido Pátria Livre (PPL), sendo eleito com 39.323 votos, em que alcançou o $34^{\circ}$ melhor desempenho entre os candidatos eleitos. No mapa abaixo é possível observar que o candidato teve forte presença eleitoral na região oeste do Estado do Paraná, ainda que tenha conquistado votos em 313 municípios dos 399. O IPE-C e os votos nestes municípios são de Cascavel IPE-C 16\% e 20.044 votos, Diamante D'oeste IPE-C 15\% e 386 votos e Ubiratã IPE-C $11 \%$ e 1.512 votos. Na cidade de Curitiba, onde o candidato teve 0,01\% de votos, ele alcançou sua segunda melhor marca de 1.340 votos. Demais municípios se destacam: São Miguel do Iguaçu IPE-C 7\% e 1074 votos, Cafelândia IPE-C 7\% e 573 votos, Santa Tereza do Oeste IPE-C 6\% e 395 votos, Vera Cruz do Oeste IPE-C 5\% e 249 votos, São José das Palmeiras IPE-C 5\% e 121 votos, Céu Azul IPE-C 5\% e 323 votos, Corbélia IPE-C 5\% e 479 votos, Iguatu IPE-C 4\% e 57 votos, Capitão Leônidas Marques IPE-C 3\% e 279 votos, Campo Bonito IPE-C 3\% e 92 votos e Lindoeste IPE-C 3\% e 121 votos. 
Revista NEP - Núcleo de Estudos Paranaenses, Curitiba, v.5, n.1, jun. 2019

FIGURA 4 - DISTRIBUIÇÃO DE VOTOS - PERCENTUAL DE VOTOS POR MUNICÍPIO MARCIO PACHECO (PPL)

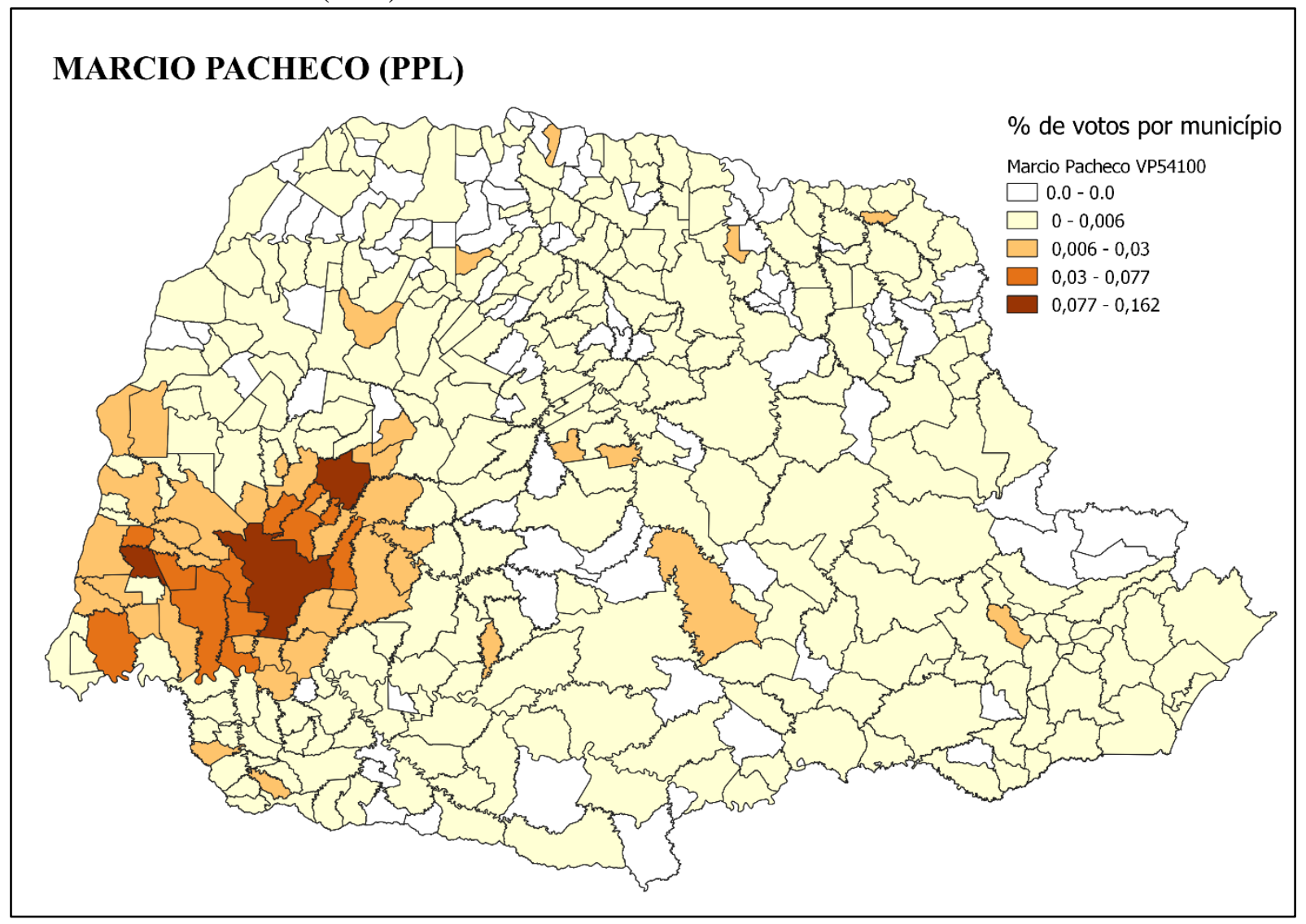

FONTE: Os autores, a partir de dados do TSE.

Manoel Batista da Silva Junior, candidato a deputado estadual pelo Partido da Mobilização Nacional (PMN), concorre com nome de urna de Dr. Batista e foi eleito com um total de 31.315 votos, alcançando o $52^{\circ}$ lugar no desempenho em conquista de votos, sendo eleito por média e tendo estes distribuídos em 181 municípios. No mapa abaixo é possível observar que ocorre uma maior concentração de votos na região Norte do Estado. O maior IPE-C se dá no município de Ângulo, com um total de 57\%, igual a 1.060 votos. No entanto, é na cidade de Maringá que ocorre a maior conquista em votos absolutos, alcançando um total de 13.599 votos, com um IPE-C de 7\%. Demais municípios conferiram votos ao candidato, Sarandi IPE-C 11\% e 4.140 votos, Paiçandu IPE-C 19\% e 3.147 votos, Jandaia do Sul IPE-C 11\% e 1.214 votos, Mandaguaçu IPE-C 10\% e 1.141 votos, Japurá IPE-C 11\% e 545 votos, Doutor Camargo IPE-C 12\% e 371 votos, São Jorge do Ivaí IPE-C 10\% e 340 votos e Atalaia IPE-C 8\% e 227 votos. 
Revista NEP - Núcleo de Estudos Paranaenses, Curitiba, v.5, n.1, jun. 2019

FIGURA 5 - DISTRIBUIÇÃO DE VOTOS - PERCENTUAL DE VOTOS POR MUNICÍPIO - DR. BATISTA (PMN)

DR. BATISTA (PMN)

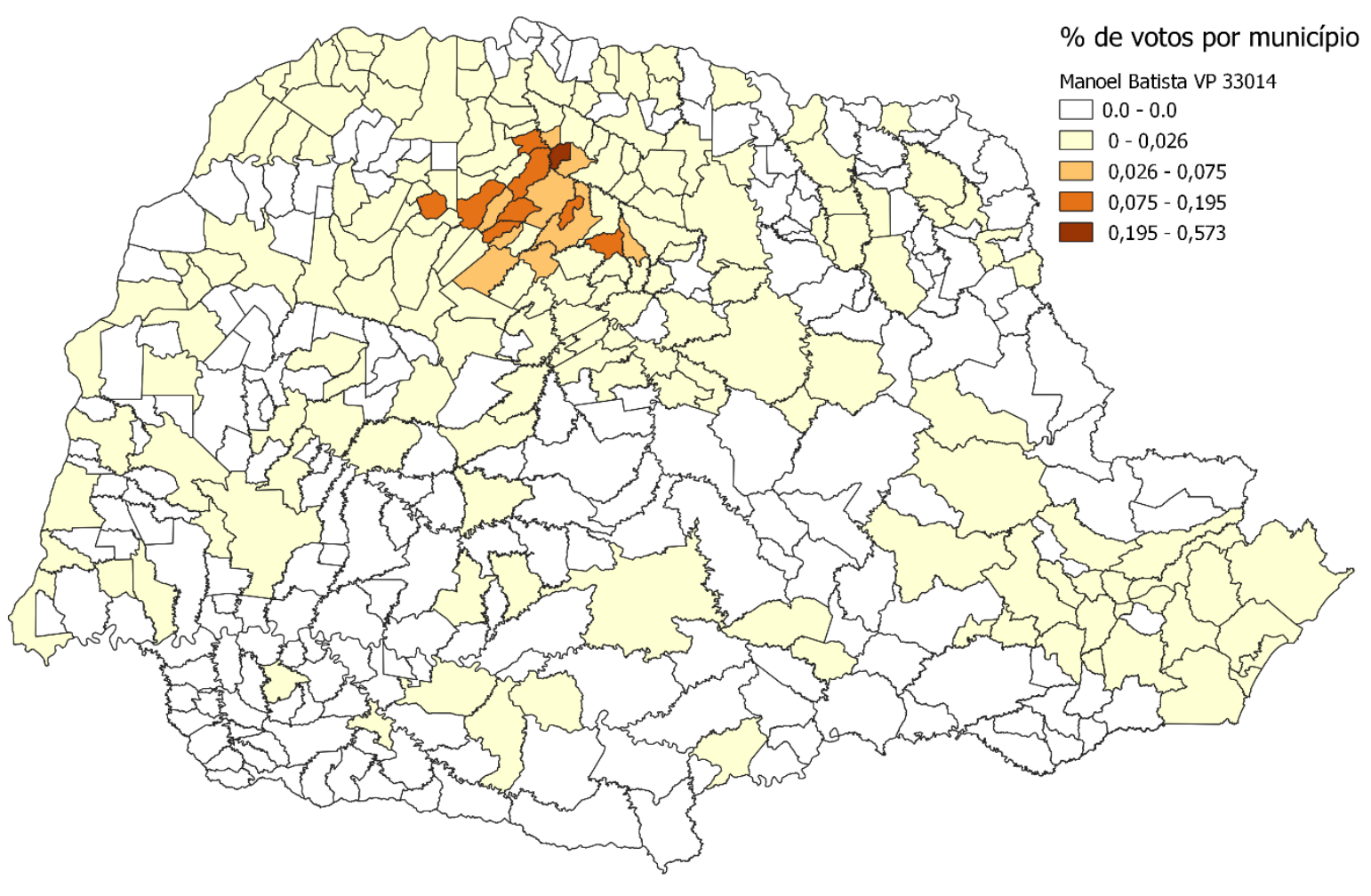

FONTE: Os autores, a partir de dados do TSE.

\section{As votações - o caso dos candidatos a Deputado Federal - Paraná}

Rubens Bueno, candidato a deputado federal pelo Partido Popular Socialista (PPS), foi eleito com um total de 76.471 votos, alcançando o $22^{\circ}$ lugar na conquista de votos, estes que foram distribuídos em 388 municípios. Os melhores IPE-C do candidato concentram-se na região de Campo Mourão, onde nesta cidade o índice alcançou $28 \%$ e um total de 13.339 votos. No entanto, a cidade em que o candidato mais conquistou votos, foi a de Curitiba, com um total de 13.753 votos, em que, devido a magnitude eleitoral da Capital Paranaense, seu IPE-C foi de apenas 1\%. Em Ubiratã a situação é semelhante, pois nesta cidade o candidato alcançou 1.686 votos e seu IPE-C é de 12\%. Sendo assim, as demais cidades se destacam pelo cálculo do índice de presença eleitoral do candidato são: Barbosa Ferraz IPE-C 25\% e 1.413 votos, Araruna IPE-C 18\% e 1.265 e Boa Esperança IPE-C $21 \%$ e 548 votos. 
Revista NEP - Núcleo de Estudos Paranaenses, Curitiba, v.5, n.1, jun. 2019

Em Campo Mourão há um predomínio político do partido PPS. O atual prefeito é Tauillo Tezzelli, além dos vereadores Elvira Schen, campeã de votos para a câmara municipal de Campo Mourão e os vereadores Sidnei Jardim e Edson Batilani, terceiro e quarto mais votado na eleição de 2016 e Jadir Soares (Pepita).

FIGURA 6 - DISTRIBUIÇÃO DE VOTOS - PERCENTUAL DE VOTOS POR MUNICÍPIO RUBENS BUENO (PPS)

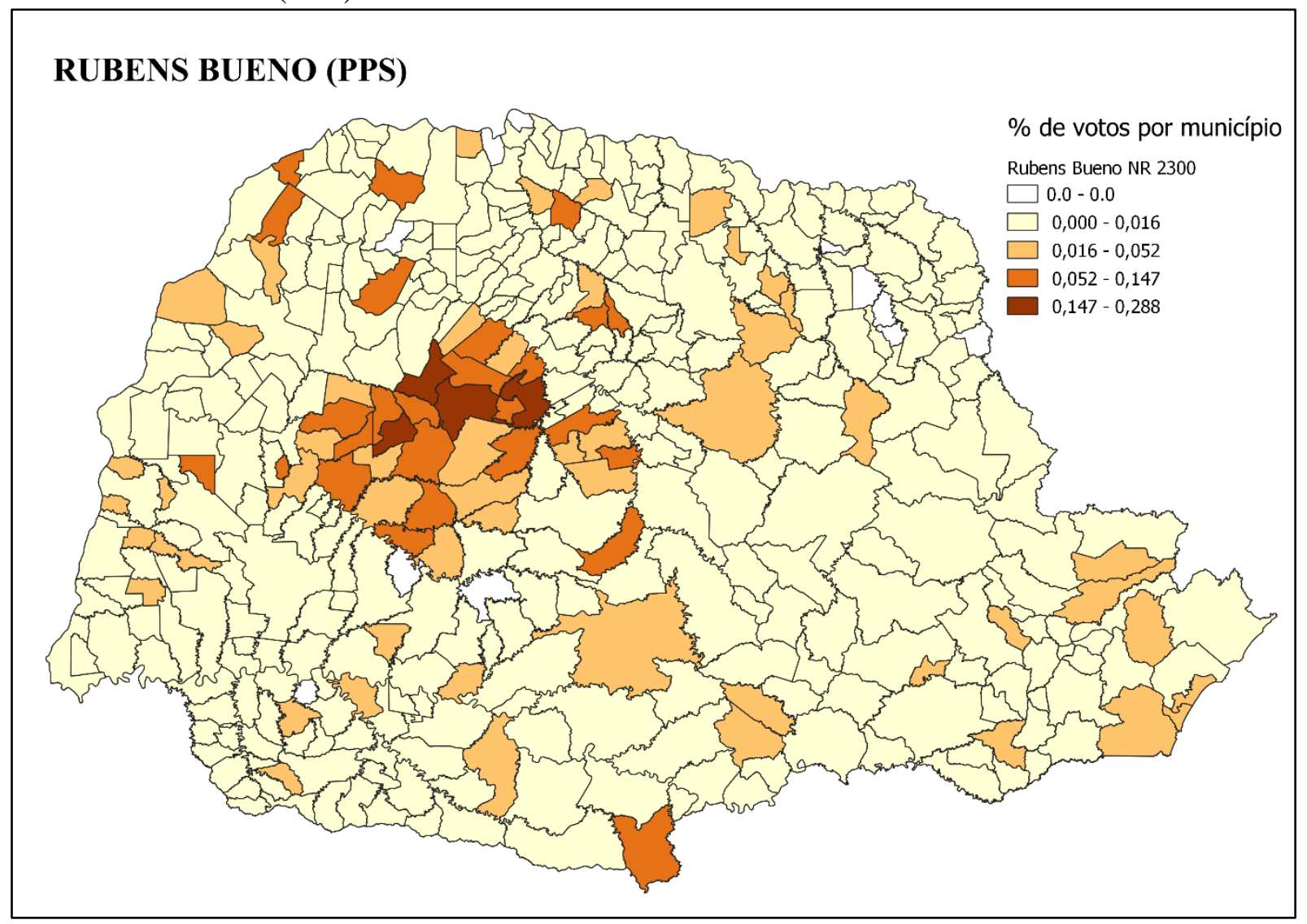

FONTE: Os autores, a partir de dados do TSE.

Pedro Deboni Lupion de Mello, candidato a deputado federal pelo Democratas (DEM), foi eleito com um total de 92.300 votos, alcançando o $17^{\circ}$ lugar na conquista de votos, estes que foram distribuídos em 318 municípios. No mapa abaixo é possível observar que o candidato apresenta os melhores IPE-C na região Nordeste do Estado do Paraná. A cidade de Figueira se destaca neste quesito onde o IPE-C do candidato é de $71 \%$, sendo um total de 3.370 votos. No entanto, é em Santo Antônio da Platina que o candidato mais obteve votos, um total de 7.800 votos e um IPE-C de $37 \%$. Os demais municípios que se destacam são Jacarezinho IPE-C 23\% (4.703 votos), Bandeirantes IPE-C 22\% 
Revista NEP - Núcleo de Estudos Paranaenses, Curitiba, v.5, n.1, jun. 2019

(4.034 votos), Juranda IPE-C 44\% (1.955 votos), Mato Rico IPE-C 31\% (618 votos) e Ivai IPE-C 20\% (1.570 votos), em demais regiões do Estado.

\section{FIGURA 7 - DISTRIBUIÇÃO DE VOTOS - PERCENTUAL DE VOTOS POR MUNICÍPIO - PEDRO LUPION (DEM)}

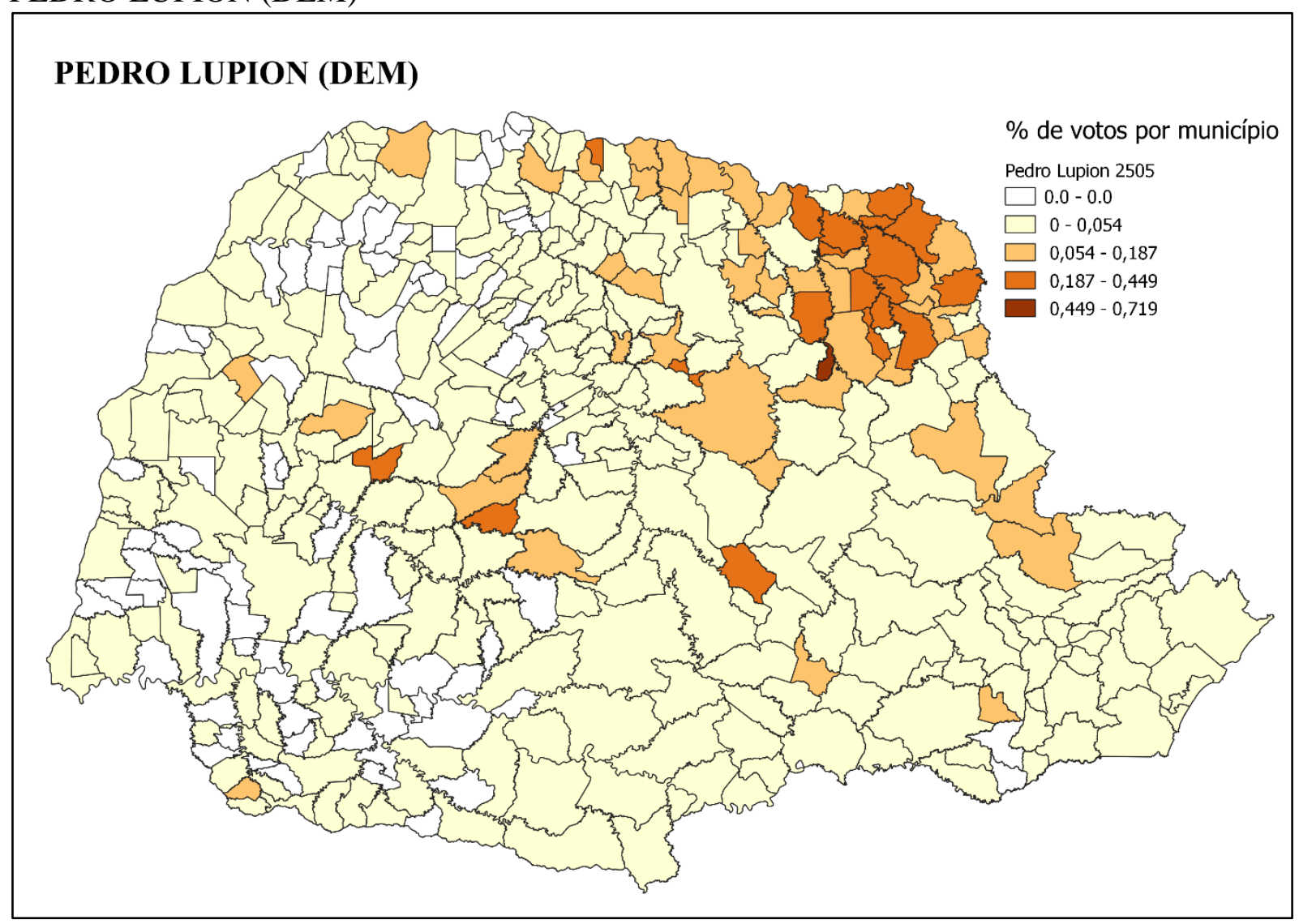

FONTE: Os autores, a partir de dados do TSE.

Hidekazu Takayama, candidato a deputado federal pelo Partido Social Cristão (PSC), conquistou um total de 53.466 votos que se distribuíram em 382 municípios, no entanto, não foram o suficiente para a sua eleição. $\mathrm{O}$ candidato alcançou a $35^{\mathrm{a}}$ maior quantidade de votos, mas que devido as regras de conquista de cadeiras por quociente, ficou como suplente, assim como demais candidatos que estavam a sua frente na conquista de votos. No mapa abaixo, é possível observar que apesar de uma excelente distribuição de votos em regiões diferentes do Estado, tal distribuição não foi suficiente para eleger o candidato. Os IPE-C's do candidato, no melhor dos recortes, fica entre 5\% e 14\%, sendo ainda em municípios de baixa magnitude eleitoral: Campina do Simão IPE-C 14\% e 337 votos; Boa Ventura de São Roque IPE-C 14\% e 494 votos; Rio Negro IPE-C 12\% e 1.892 votos; e Porto Amazonas IPE-C 10\% e 237 votos. Em votos absolutos, é na Capital que o candidato tem seu melhor desempenho, alcançando 9.707 votos e IPE-C 1\%, seguido de São José dos Pinhais com 2.024 votos 
Revista NEP - Núcleo de Estudos Paranaenses, Curitiba, v.5, n.1, jun. 2019

e IPE-C 1,6\% e Rio Negro, citado anteriormente. Diante dos atuais dados, verifica-se que a região metropolitana é o forte do candidato, ainda com Colombo IPE-C 2\% e 1.824 votos, Araucária 1.518 votos e IPE-C 2,6\% e Fazenda Rio Grande IPE-C 2,4\%) e 1.048 votos.

FIGURA 8 - DISTRIBUIÇÃO DE VOTOS - PERCENTUAL DE VOTOS POR MUNICÍPIO TAKAYAMA (PSC)

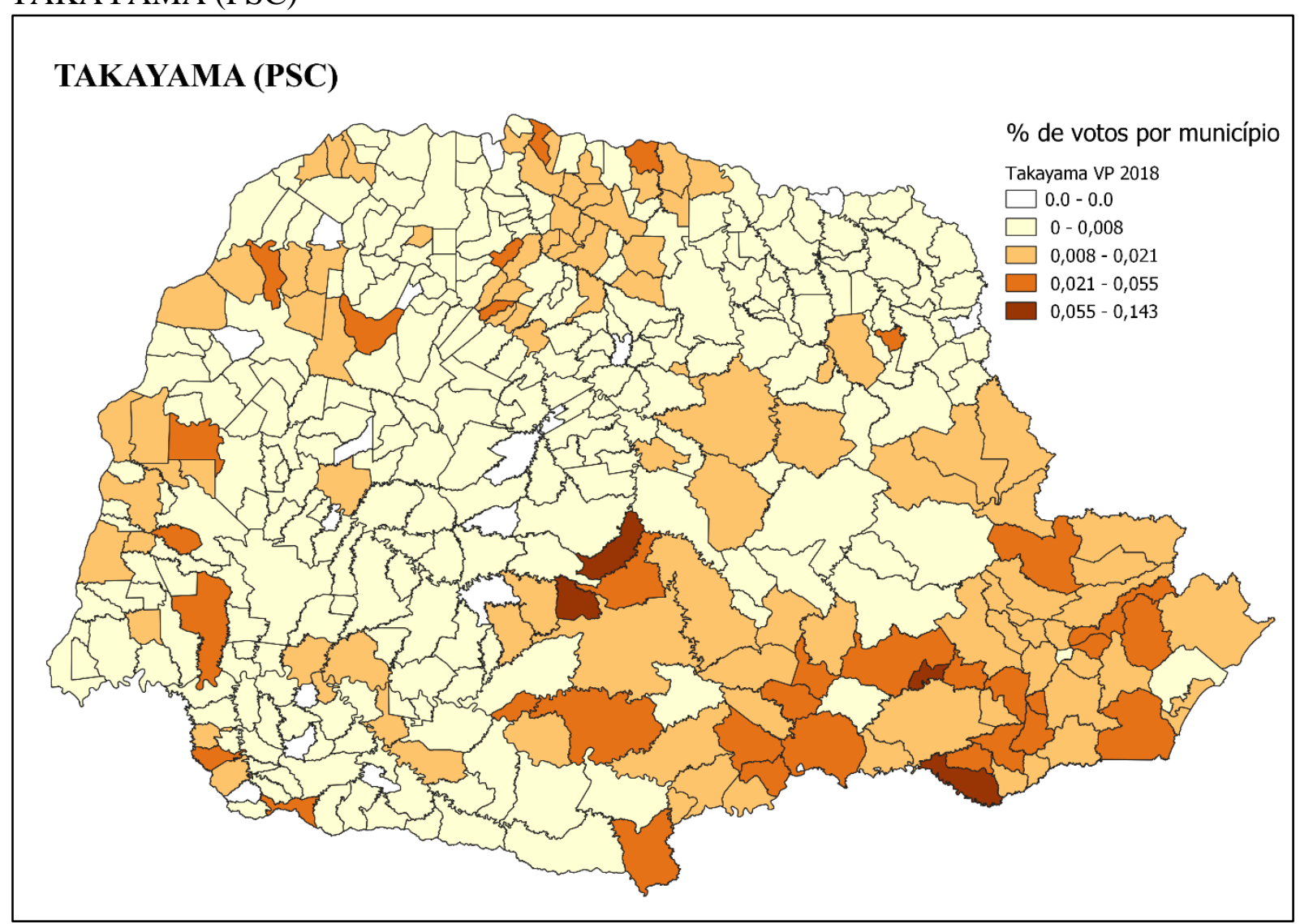

FONTE: Os autores, a partir de dados do TSE.

Fernando Lúcio Giacobo concorreu como deputado federal pelo Partido da República (PR) e foi eleito com um total de 111.384 votos, sendo o $9^{\circ}$ candidato mais votado e tendo seus votos distribuídos em 325 municípios. No mapa abaixo é possível observar que os melhores IPE-C's do candidato estão em uma faixa que pega as regiões Centro-sul e Oeste do Estado. Os melhores IPE-C's do candidato são nos municípios de: Santa Cruz de Monte Castelo IPE-C 49\% e 2.363 votos, Manoel Ribas IPE-C $30 \%$ e 2.270 votos, IPE-C Palmital 29\% e IPE-C 2.194 votos, IPE-C Nova Tebas 31\% e 1.327 votos, Diamante do Sul IPE-C $48 \%$ e 1.052 votos. O lugar onde mais fez votos é no município de Foz do Iguaçu, um total de 10.080 votos e um IPE-C de $8 \%$. 
Revista NEP - Núcleo de Estudos Paranaenses, Curitiba, v.5, n.1, jun. 2019

FIGURA 9 - DISTRIBUIÇÃO DE VOTOS - PERCENTUAL DE VOTOS POR MUNICÍPIO GIACOBO (PR)

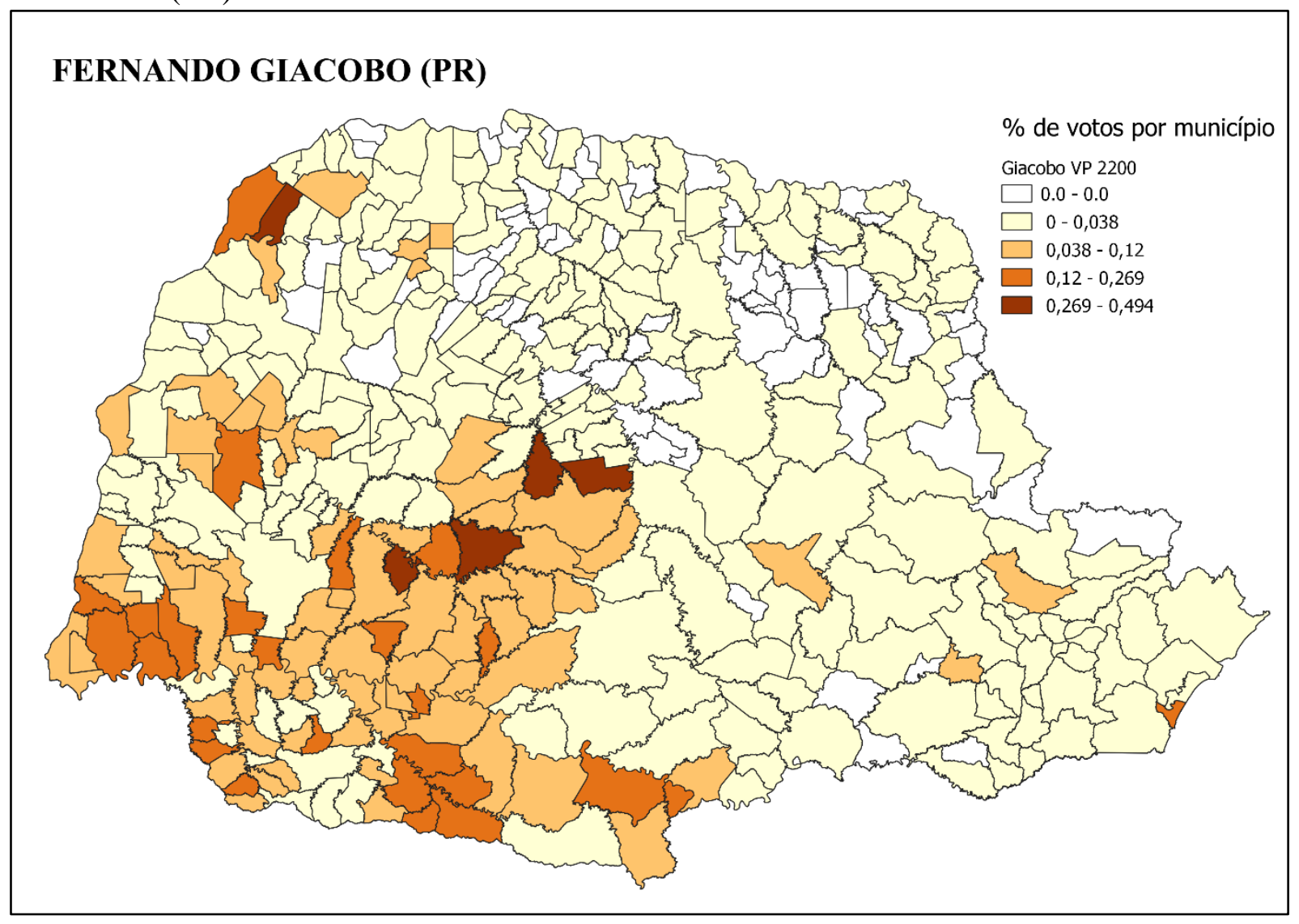

FONTE: Os autores, a partir de dados do TSE.

Antônio Wandscheer foi candidato a deputado federal pelo PROS e conquistou um total de 72.475 votos, distribuídos em 298 cidades, sendo o $26^{\circ}$ mais votado. No mapa abaixo é possível observar que o candidato não possui padrão de distribuição de votos bem definido e que se concentre mais em alguma região. Note-se que é mais fácil dizer que ele não faz votos na região Noroeste do Estado. Sendo assim, os municípios com melhores IPE-C são: Nova América da Colina IPE-C 59\% e 1.286 votos, Santo Antônio do Paraíso IPE-C 33\% e 545 votos, Sapopema 32\% e 1.081 votos, São João do Triunfo IPE-C $30 \%$ e 2.349 votos. As maiores conquistas de votos são em Fazenda Rio Grande, com 6.389 votos e IPE-C 14\% e Curitiba, com 3.738 e IPE-C de 0,004\%.

Alguns dados nos soam estranhos quanto a análise do candidato Toninho Wandscheer e que destoam dos demais achados nessa pesquisa. Primeiro, no município de Nova América da Colina/PR onde Toninho foi o campeão de votos com $59 \%$ dos votos daquele município para candidato a deputado federal, seu filho, Alisson Wandscheer (PMB) obteve apenas um voto. Em Sapopema/PR, seu filho 
Revista NEP - Núcleo de Estudos Paranaenses, Curitiba, v.5, n.1, jun. 2019

obteve apenas cinco votos. Em São João do Triunfo/PR, Alisson Wandscheer obteve 264 votos, cerca de $3 \%$ dos votos a deputado estadual naquele município.

Em Fazenda Rio Grande/PR, reduto eleitoral da família, onde seu pai Toninho ficou em segundo lugar mais votado com 6.389 votos, cerca de $13 \%$ dos votos a deputado federal de fazenda Rio Grande, Allison foi o terceiro candidato a deputado estadual mais votado com 2973 votos, cerca de $6 \%$ dos votos daquele município. Podemos concluir que a dobradinha Pai/Filho Wandscheer funcionou apenas na região metropolitana de Curitiba, pois no interior, o resultado eleitoral do filho Alisson foi pífio.

FIGURA 10 - DISTRIBUIÇÃO DE VOTOS - PERCENTUAL DE VOTOS POR MUNICÍPIO TONINHO WANDSCHEER (PROS)

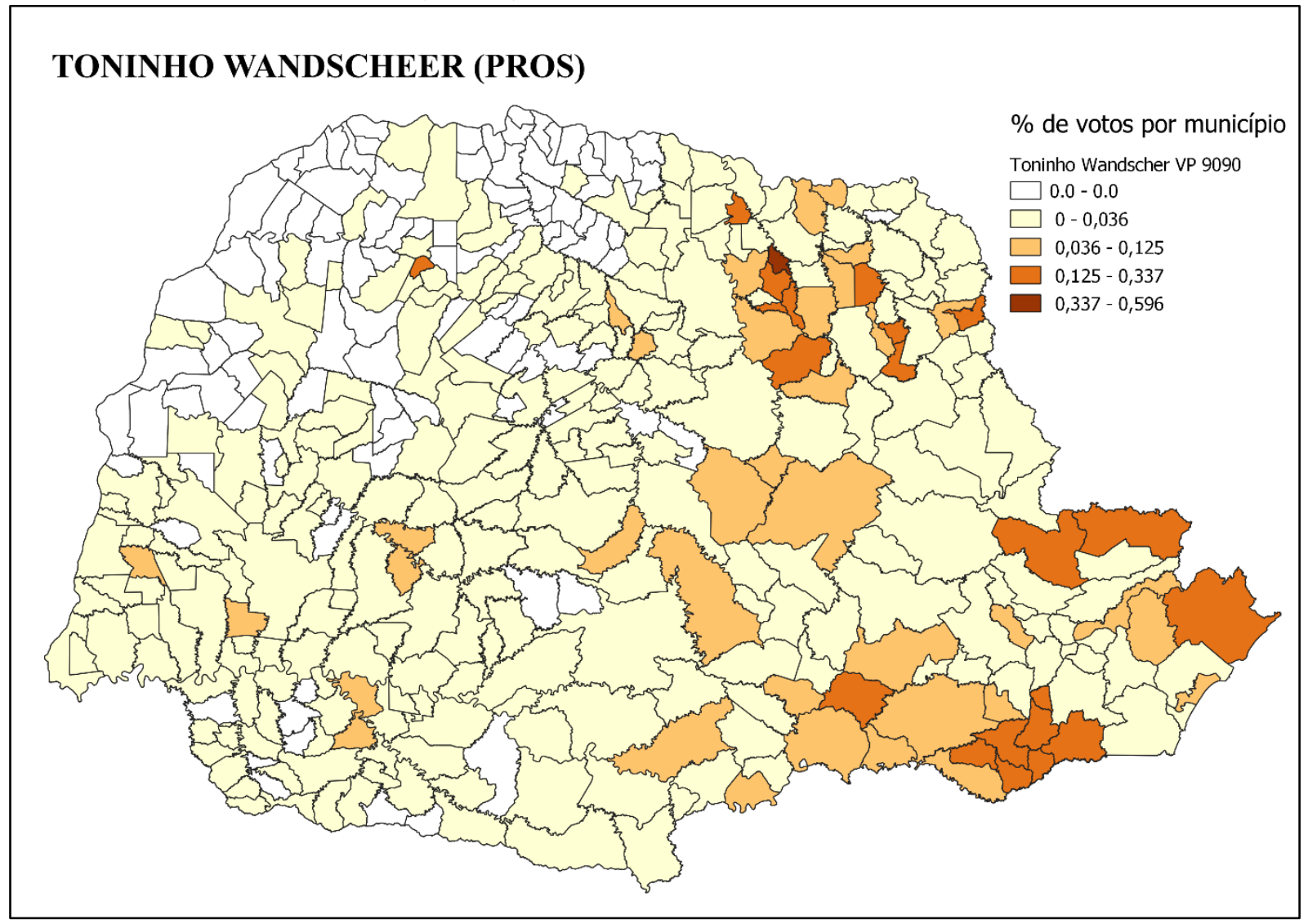

FONTE: Os autores, a partir de dados do TSE. 
Revista NEP - Núcleo de Estudos Paranaenses, Curitiba, v.5, n.1, jun. 2019

Alex Canziani, candidato a Senador pelo Partido Trabalhista Brasileiro (PTB), foi o quarto candidato mais votado conquistando um total de 1.304 .719 votos distribuídos nos 399 municípios paranaenses. $\mathrm{O}$ candidato registrou IPE-C superior a $25 \%$ em pelo menos 50 municípios que se localizam na faixa Norte do Paraná, onde destacamos os seguintes: Santa Cecília do Pavão IPE-C 38\% sendo 1.574 votos, Astorga IPE-C 37\% sendo 9.472 votos, Assaí IPE-C 34\% sendo 5.501 votos, Apucarana IPE-C 30\% sendo 35.060 votos. No entanto, os municípios onde o candidato mais conquistou votos foram: Curitiba IPE-C de 7\% sendo 135.991 votos, Londrina IPE-C $21 \%$ sendo 98.887 votos, Maringá IPE-C 15\% sendo 53.556 votos, Ponta Grossa IPE-C 11\% sendo 35.757 votos e Foz do Iguaçu IPE-C 14\% sendo 35.579 votos.

FIGURA 11 - DISTRIBUIÇÃO DE VOTOS - PERCENTUAL DE VOTOS POR MUNICÍPIO ALEX CANZIANI (PTB)

\section{ALEX CANZIANI (PTB)}

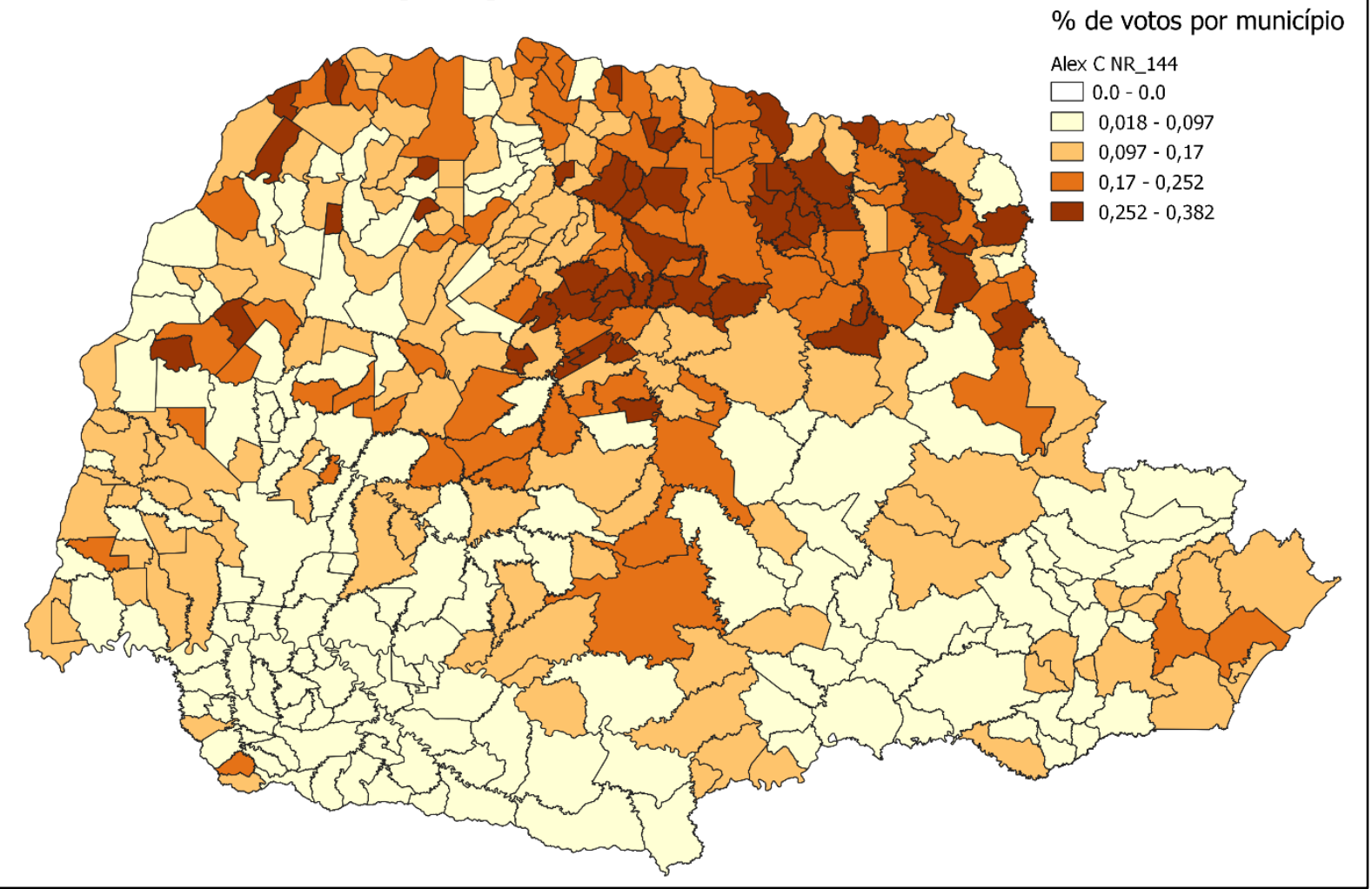

FONTE: Os autores, a partir de dados do TSE.

As votações - o caso dos candidatos a Governador - Paraná 
Revista NEP - Núcleo de Estudos Paranaenses, Curitiba, v.5, n.1, jun. 2019

Dr. Rosinha, candidato a Governador pelo Partido dos Trabalhadores (PT), foi o quarto candidato mais votado conquistando um total de 463.494 votos distribuídos nos 399 municípios do Paraná. O candidato registrou IPE-C superior a 23\% em pelo menos 20 municípios, sendo destaque o município de Rio Bonito do Iguaçu IPE-C 46\% sendo 3.771 votos. No entanto, entre os municípios em que mais conquistou votos destacamos: Curitiba IPE-C 8\% sendo 71.291 votos, Cascavel IPE-C 10\% sendo 15.720 votos, Maringá IPE-C 7\% sendo 14.694 votos, Londrina IPE-C 5\% sendo 12.487 votos e Guarapuava IPE-C 13\% sendo 11.756 votos.

FIGURA 12 - DISTRIBUIÇÃO DE VOTOS - PERCENTUAL DE VOTOS POR MUNICÍPIO - DR. ROSINHA (PT)

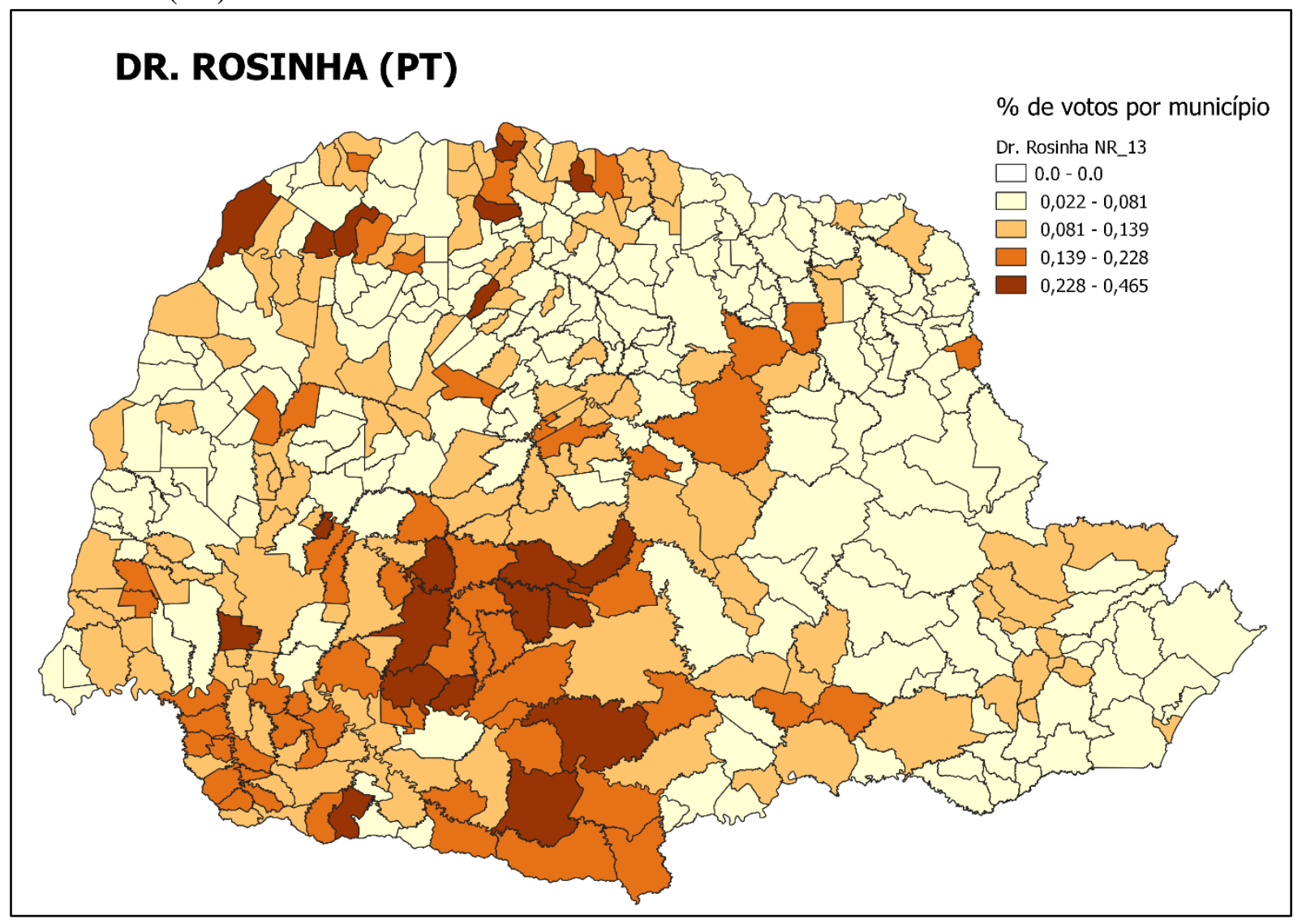

FONTE: Os autores, a partir de dados do TSE.

Ratinho Jr., candidato eleito a Governador pelo Partido Social Democrático (PSD) conquistou 3.210.712 votos distribuídos nos 399 municípios do Paraná. O candidato registrou IPE-C superiores a 68\% em pelo menos 77 municípios e superiores a 50\% em nada menos que 318 municípios. Damos destaque para os municípios de: São Jorge do Patrocínio IPE-C 86\% sendo 3.186 votos, Arapongas IPE-C $81 \%$ sendo 44.148 votos e Apucarana IPE-C $78 \%$ sendo 48.767 votos. Demais municípios onde 
Revista NEP - Núcleo de Estudos Paranaenses, Curitiba, v.5, n.1, jun. 2019

Dossiê Partidos Políticos e Conexões Familiares

ISSN: 2447-5548

os valores absolutos em votos se destacam são: Curitiba IPE-C 60\% sendo 520.832 votos, Londrina IPE-C $61 \%$ sendo 144.375 votos e Ponta Grossa IPE-C 61\% sendo 97.424 votos.

FIGURA 13 - DISTRIBUIÇÃO DE VOTOS - PERCENTUAL DE VOTOS POR MUNICÍPIO RATINHO JR. (PSD)

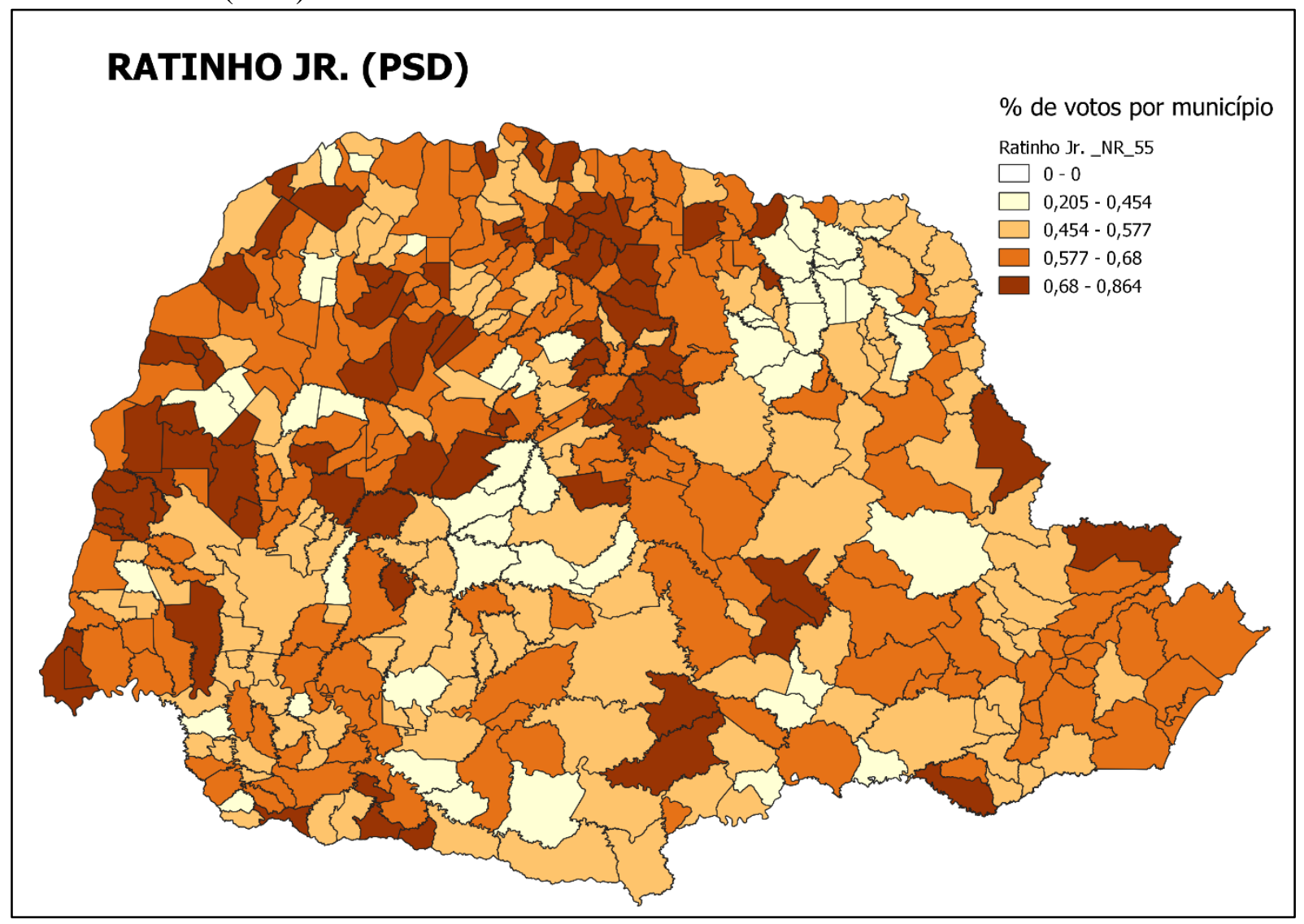

FONTE: Os autores, a partir de dados do TSE.

João Arruda, candidato a Governador pelo Movimento Democrático Brasileiro (MDB) foi o terceiro candidato mais votado com 705.976 votos distribuídos nos 399 municípios do Paraná. O candidato registrou IPE-C superiores a 32\% em pelo menos 14 municípios. Destacamos os seguintes: Bandeirantes IPE-C 62\% sendo 11.285 votos e Castro IPE-C 39\% sendo 13.9115 votos. Em quantia de votos destacamos: Curitiba IPE-C 11\% sendo 95.256 votos, Londrina IPE-C $12 \%$ sendo 28.684 votos e Ponta Grossa IPE-C 15\% sendo 24.769 votos. 
Revista NEP - Núcleo de Estudos Paranaenses, Curitiba, v.5, n.1, jun. 2019

FIGURA 14 - DISTRIBUIÇÃO DE VOTOS - PERCENTUAL DE VOTOS POR MUNICÍPIO JOÃO ARRUDA (MDB)

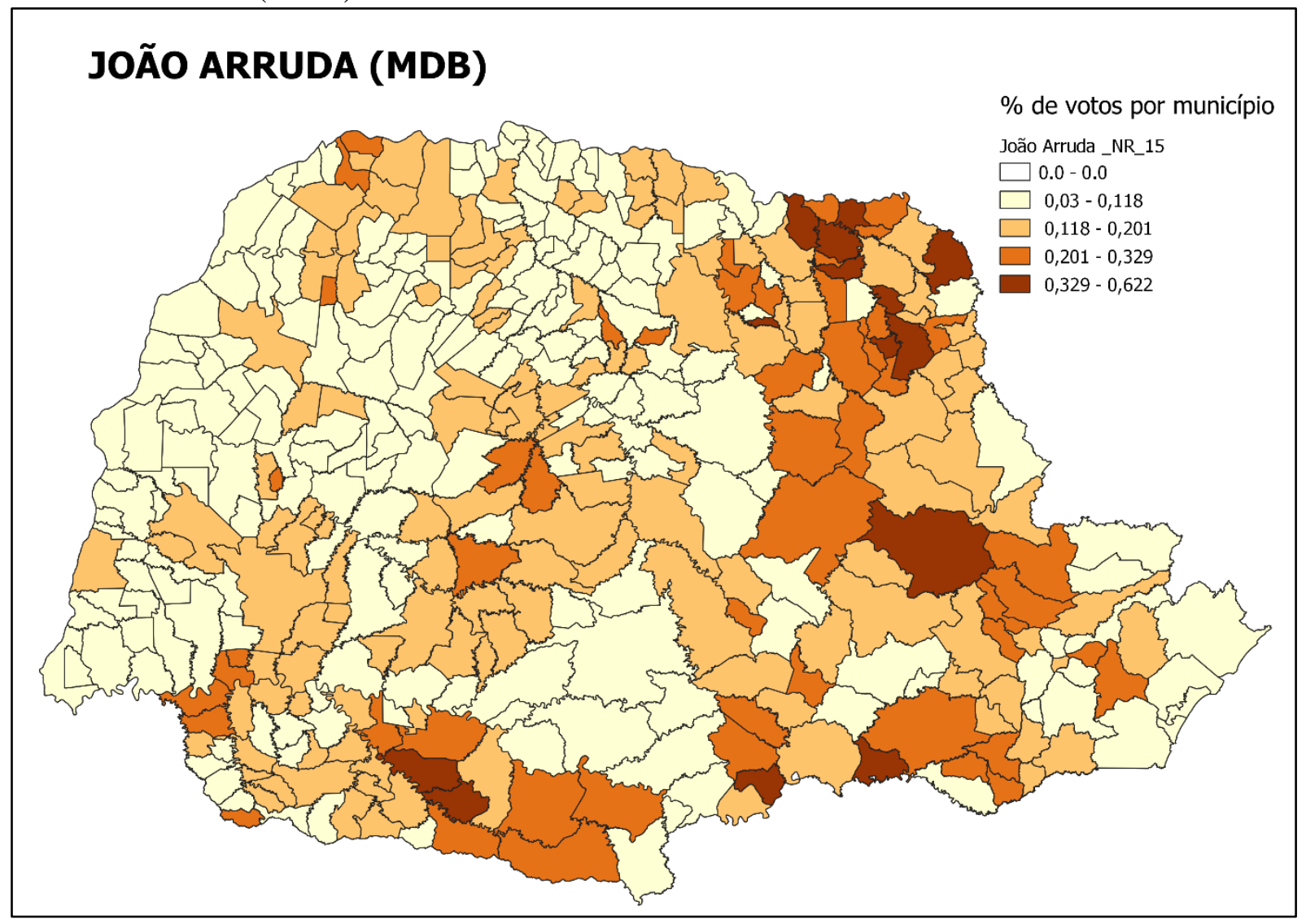

FONTE: Os autores, a partir de dados do TSE.

Geonisio Cesar Marinho, candidato a Governador pelo Partido Renovador Trabalhista Brasileiro (PRTB) foi o sétimo candidato mais votado com 18.021 votos conquistados distribuídos em 377 municípios do Paraná. Os IPE-C registrados pelo candidato são pouco expressivos perto dos demais citados acima, sendo nunca superior $1 \%$. Curitiba é o local em que o candidato mais conquistou votos, sendo um total de 5.768 votos. 
Revista NEP - Núcleo de Estudos Paranaenses, Curitiba, v.5, n.1, jun. 2019

FIGURA 15 - DISTRIBUIÇÃO DE VOTOS - PERCENTUAL DE VOTOS POR MUNICÍPIO GEONISIO MARINHO (PRTB)

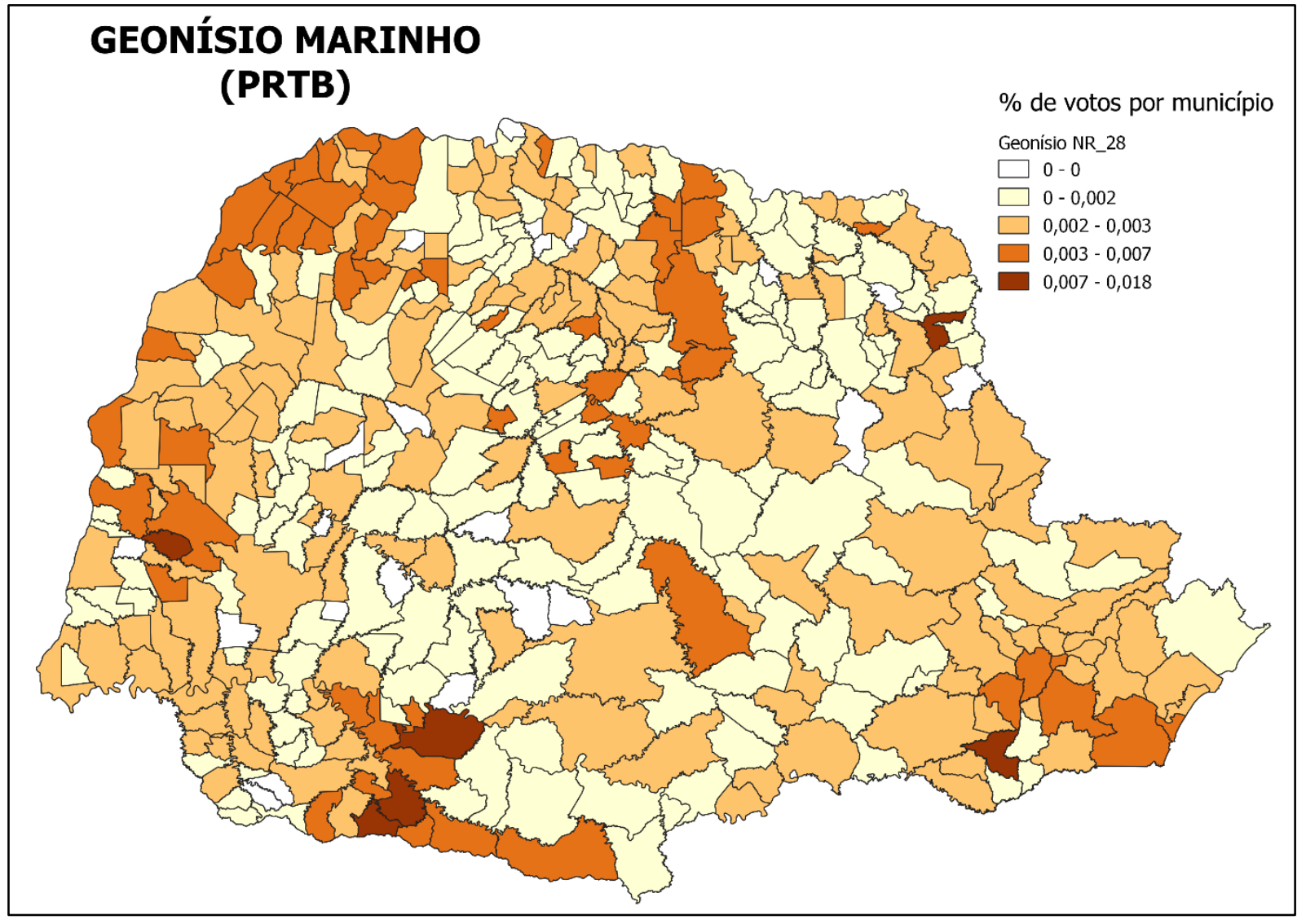

FONTE: Os autores, a partir de dados do TSE.

\section{A discussão e os resultados}

Muitos são os estudos que em um sentido próximo ao deste trabalho, buscam determinantes do voto, apontando para variáveis como partido político, partido de apoio do chefe do executo acima, tipo de mandato, magnitude do distrito, gênero, carreira, entre outros (MANCUSO, 2015). Sendo assim, mediante a nossa hipótese, vimos que possuir um histórico político e familiar é significativo para a conquista da presidência de Partidos Políticos no Paraná. Por sua vez, a presidência de partidos, ao que indica a nossa pesquisa, tem promovido condições de atuação política sobre algumas regiões do Estado.

Este trabalho pôde contribuir para com as determinantes em que ser presidente de partido político no Paraná impacta consideravelmente para a compreensão das possíveis estratégias eleitorais de conquista de votos. Destacamos que dos 15 casos analisados, pelo menos oito, mais da metade, 
Revista NEP - Núcleo de Estudos Paranaenses, Curitiba, v.5, n.1, jun. 2019

possuem amplas redes de parentesco e histórico familiar, muitas vezes misturando-se entre si casos das famílias Bueno e Borghetti, sugerindo uma ideia de que por vezes, os partidos políticos no Paraná são "propriedades" de poucas, mas poderosas famílias políticas ${ }^{26}$.

De maneira geral, estabelecemos relações entre as questões de parentesco e genealogia e seus resultados eleitorais em 2018. Como resultado, percebemos que é visível o favorecimento dos filhos dos presidentes Francischini (PSL), Rubens Bueno (PPS), Abelardo Lupion (DEM), Ricardo Barros/Cida Borhgetti (PP), Alex Canziani (PTB), respectivamente: Felipe Francischini (PSL), Renata Bueno (PPS), Pedro Lupion (DEM), Maria Victoria (PP) e Luisa Canziani (PTB). Por fim, destacamos situações de privilégio tanto na rápida ascensão política, quanto nos resultados eleitorais dos mesmos, como presidente da CCJC federal em primeiro mandato (Felipe Francischini), eleição para vereadora por Curitiba e deputada italiana (Renata Bueno), vice líder do governo federal em primeiro mandato (Pedro Lupion), a jovem maringaense candidata a prefeita de Curitiba com 27 anos (Maria Victoria), e a deputada mais jovem da atual legislatura do Congresso Nacional (Luisa Canziani). Além é claro de inaugurarmos uma agenda de pesquisa sobre a genealogia familiar/política do atual governador do Paraná, Ratinho Júnior.

Concluímos que o nepotismo se aproveita da fragilidade das instituições políticas. Aliado às desigualdades sociais, à patronagem e ao clientelismo político, o nepotismo desenvolve formas de um sistema político próprio. É uma estratégia de classes e de famílias para a conquista, manutenção e exercício do poder pelas redes do parentesco que perpassam as presidências dos partidos políticos e impactam nas estratégias/resultados de campanhas/eleições no Paraná.

\section{REFERÊNCIAS}

COELHO, Nicole Paes. O clã Malucelli - trajetória, empreendimento e principais atores no Paraná. Revista NEP (Núcleo de Estudos Paranaenses), Curitiba, v.3, n.1, p. 17-35, maio 2017.

MACHADO, Vanderlei Hermes. Do berço ao túmulo: família e cartórios no Paraná. 208 f. Dissertação (Mestrado em Sociologia) - Universidade Federal do Paraná, Curitiba, 2016.

\footnotetext{
${ }^{26}$ São os oito casos destacados: Fernando Francischini (PSL), Maria Victoria (PP) eleitos deputados estaduais. Dos candidatos a deputados federais Rubens Bueno (PPS), Pedro Lupion (DEM) e Toninho Wandscheer (PROS) eleitos. Por último analisamos o candidato ao senado Alex Canziani (PTB), não eleito e os candidatos ao governo do Paraná, Joao Arruda (MDB), e Carlos Massa Júnior (Ratinho Jr - PSD), esse último, eleito governador.
} 
Revista NEP - Núcleo de Estudos Paranaenses, Curitiba, v.5, n.1, jun. 2019

MANCUSO, Wagner Pralon. Investimento eleitoral no Brasil: balanço da literatura (2001-2012) e agenda de pesquisa. Revista de Sociologia e Política, v. 23, n. 54, p. 155-183, 2015.

MATHEUS, Sandoval. O clã mais poderoso da província. Disponível em:

<https://www.plural.jor.br/o-cla-mais-poderoso-da-provincia/>. Acesso em: març. 2019).

OLIVEIRA, Ricardo Costa de. Na teia do nepotismo. Curitiba: Insight, 2012.

PEREIRA, Fernando Marcelino. Maria Victória (PP), herdeira das velhas oligarquias. Disponível em: < https://www.brasildefato.com.br/2016/09/26/maria-victoria-pp-herdeira-das-velhasoligarquias/. > Acesso em: mar. 2019.

RESENDE, Daiane. "Requião tem razão?" Homem político e discursos: um estudo sobre a trajetória de Roberto Requião De Mello E Silva. 2015. Tese (Doutorado em Ciências Sociais). Universidade Federal do Paraná, Curitiba.

Recebido em: 14 maio 2019

Aceito em: 10 jun. 2019 